EGPS Party profile series

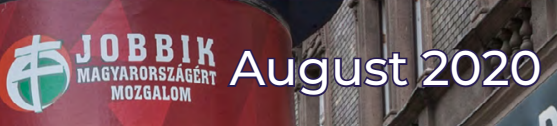

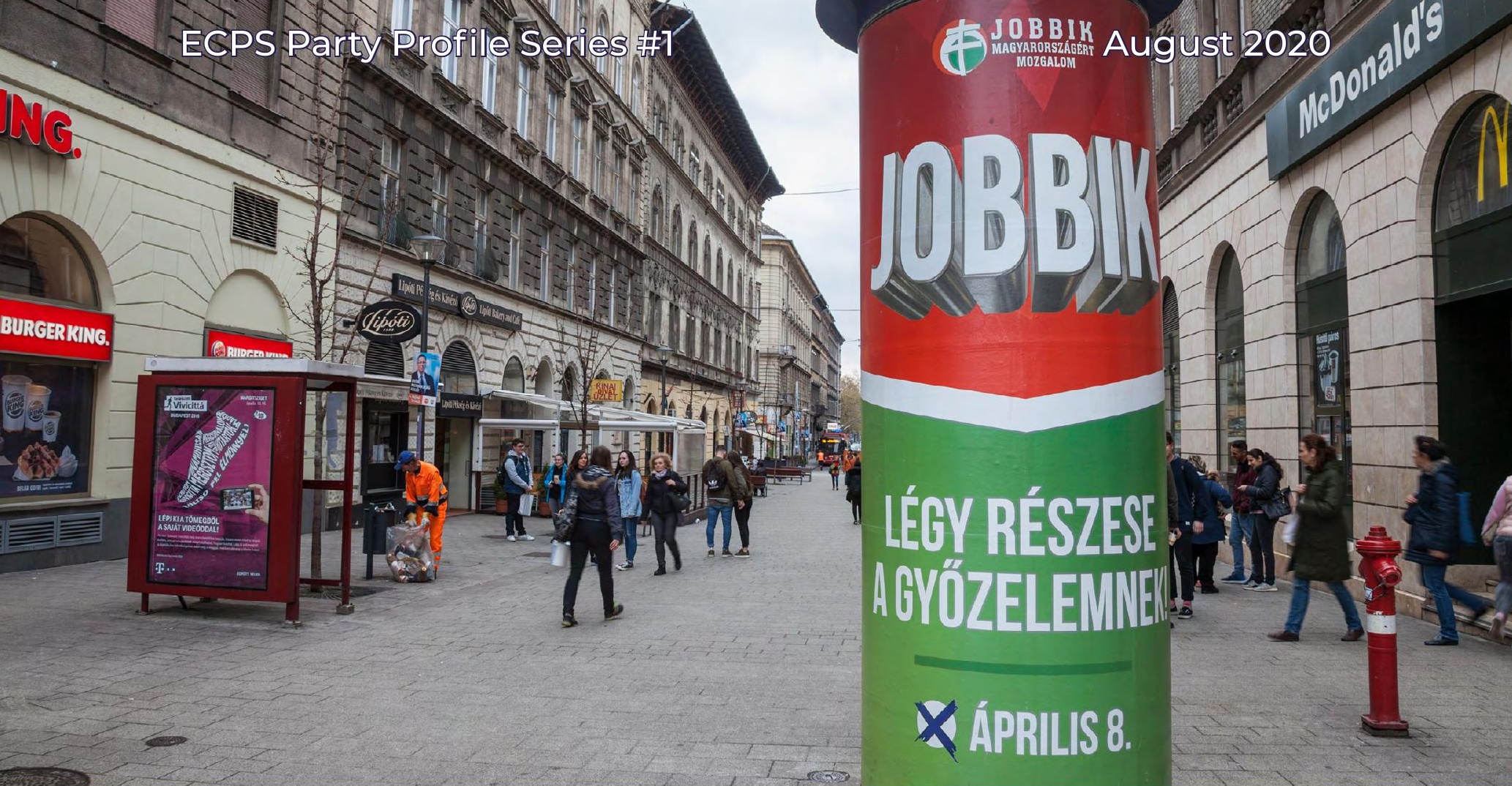

AUTHOR: Bulent Kenes

\title{
Jobbik: A Turanist Trojan Horse in Europe?
}

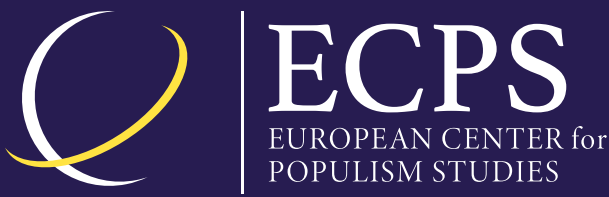




\section{Jobbik: A Turanist Trojan Horse in Europe?}

BY BULENT KENES

\section{ABSTRACT}

Defined as Turanist, Eurasianist, pro-Russian, pro-Iranian, anti-immigrant but pro-Islam, racist, antisemitic, anti-Roma, Hungarist, and radically populist, Jobbik do not exist in a vacuum. The rise of Jobbik from deep nationalist, antisemitic, and anti-Roma currents in Hungarian politics dates back to the late 1980s and early 1990s. Despite its extensive efforts at "image refurbishment" in recent years, Jobbik remains a populist, revisionist, racist, radical right-wing party that threatens to destabilize Hungary, the neighboring region, and the EU.

BULENT KENES is an academic and a journalist who has over 25 years of professional experience. He has managed multiple publications, both in Turkish and English.

ECPS Leader Profile Series offer analyses of political leaders and prominent public figures with populist tendencies. Unless otherwise indicated, the views expressed by the author are only attributable him and not to any institution with which they are associated.

The profile available for free downloading from the ECPS website (wwW. populismstudies.org)

(c)ECPS 2021 


\section{Table of contents}

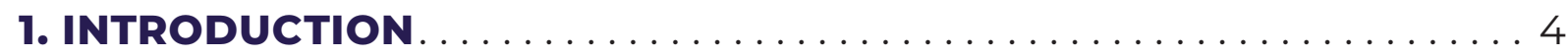

2. RACIST REINCARNATION IN A DIGITAL AGE $\ldots \ldots \ldots \ldots \ldots \ldots \ldots 7$

3. MORE THAN A POLITICAL PARTY $\ldots \ldots \ldots \ldots \ldots \ldots \ldots \ldots \ldots$

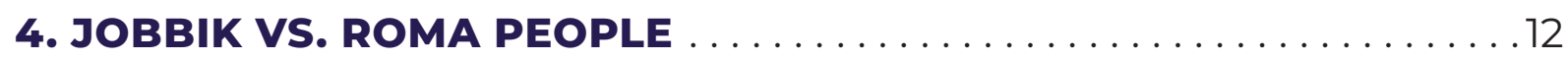

5. ANTISEMITISM AND HUNGARISM $\ldots \ldots \ldots \ldots \ldots \ldots \ldots \ldots \ldots \ldots$

6. UNIQUE AMONG EUROPEAN RACISTS: AN ISLAM-FRIENDLY JOBBIK

7. TRACING THE FOOTSTEPS OF IMAGINED ANCESTORS:

TURANISM

8. "EASTERN TURN" \& TIES WITH RUSSIA, IRAN, AND TURKEY . . . . 27

CONCLUSION 


\section{INTRODUCTION}

The collapse of the communist regime and the transition to a liberal market economy in the early 1990s precipitated major shifts in Hungarian society. Almost one million people lost their jobs, while income inequality increased markedly and wages and living standards shrank. Facing uncertain futures, large sectors of society viewed themselves as the "losers" of this transition. Extreme poverty reappeared amidst austerity measures initiated by the government. The rise in economic uncertainty and the hardships of transition increased the popularity of political parties pushing for radical solutions (Pap \& Glied, 2018). As a consequence of this, since the end of communism there has been widespread support for the political far right in Hungary.

During the past 30 years, the symbolic politics of "national revival" have evolved into a daily politics characterized by anti-Semitism, anti-liberalism, and anti-Roma expressions (Murer, 2015). Hungary, an erstwhile poster boy of neoliberal transformation in the region, openly proclaimed itself as a prototypical "illiberal regime." This climate has also created a fertile ground for more radical movements and populist parties. Thus, the far-right Jobbik, which has affiliated paramilitary organizations, has become the second largest party in the Hungarian parliament (Fabry \& Sandbeck 2019). But what is Jobbik? Who are the people who have been mobilized by the party which is paradoxically defined as Turanist, Eurasianist, pro-Russian, pro-Iranian, anti-immigrant but pro-Islam, racist, antisemitic, anti-Roma, Hungarist, and radically populist?

The Movement for a Better Hungary (Jobbik Magyarországért Mozgalom) (Jobbik.com) was established as a new generation radical right political party. It is commonly known by its abbreviated name "Jobbik," which is in fact a play on words. The word "jobb" in Hungarian has two meanings: an adjective, meaning "better," and adverb, meaning the direction "right." The comparative "Jobbik" therefore means both "the more preferable choice" and "more to the right." This is similar to the English phrase "right choice," which could mean both "a choice on the right side of the political spectrum" and "a correct choice" (Murer, 2015).

Actually, the current radical right and Jobbik do not exist in a vacuum. The rise of Jobbik from deep nationalist, antisemetic, and anti-Roma currents in Hungarian politics dates back to the late 1980s and early 1990s (Murer, 2015). In the period since the political transition to democracy in post-Communist Central and Eastern Europe (CEE), nationalists and radical-right parties were either newly formed or reemerged. In this transitional context, Hungary has come to be seen as a stronghold of the radical right (Kim, 2016). However, of all the radical-right Hungarian parties that existed in the 1990s, the only one to have electoral success was the Hungarian Truth and Life Party (Magyar Igazság és Élet Pártja - MIÉP) led by novelist István Csurka (Akçalı \& Korkut 
2012; Murer, 2015).

MIÉP was one of the most extreme far-right parties in Europe (Mudde, 2007). As the chief representative of the radical right in contemporary Hungary, Jobbik is in many ways the successor of MIÉP, which seceded in 1993 from the then-governing party Hungarian Democratic Forum (Magyar Demokrata Fórum - MDF). MIÉP's ideology incorporated an anti-EU sentiment and nationalist and Christian values alongside anti-liberal, anti-democratic, and anti-globalization elements. MIÉP focused its ire especially on international financial groups, global capital, communists, Jews, and liberals who, it claimed, controlled global trends and wished to "re-colonize" Hungary by regaining their former power over post-communist Hungary. In 1998 , the party gained seats in parliament but did not reach the necessary five-percent threshold in 2002 and thus lost its seats (Pap \& Glied, 2018; Kim, 2016). When Jobbik was established as a political movement in 1999 by university students, they learned from MIÉP's failure.

Preceding MIÉP by many decades, Hungary was briefly governed by the fascist Arrow Cross party (Nyilaskeresztes Párt) following Nazi Germany's intervention in 1944. The Arrow Cross helped the Nazis to organize the extermination of Hungarian Jews.

Both of these previous radical-right parties influenced Jobbik. The founders of Jobbik claimed publicly to be inspired by MIÉP. Though the Arrow Cross party is not officially cited as an influence, Jobbik's use of its symbols, such as the Árpád stripes, is a clear reminder of the Hungarian fascist era. This is natural because the constant reference to the past is particularly crucial for radical-right parties, since national history is usually a key element of their ideology (Karl, 2017).

Jobbik, as a party even more radical nationalist than MIÉP, wields increasing influence on the mainstream stage. Its success is a unique post-transitional political development that represents the central elements of Hungarian nationalism. These include an underlying social prejudice against Jews and Roma; anti-liberal capitalism; and an attraction to the historical narrative of mythic Turanism in the debate over the origins of Hungarian national identity. Jobbik manipulates all of these national elements in shaping its identity (Kim, 2016). In many ways Jobbik is similar to other European far-right groups, although it features several characteristics that make it unique. 


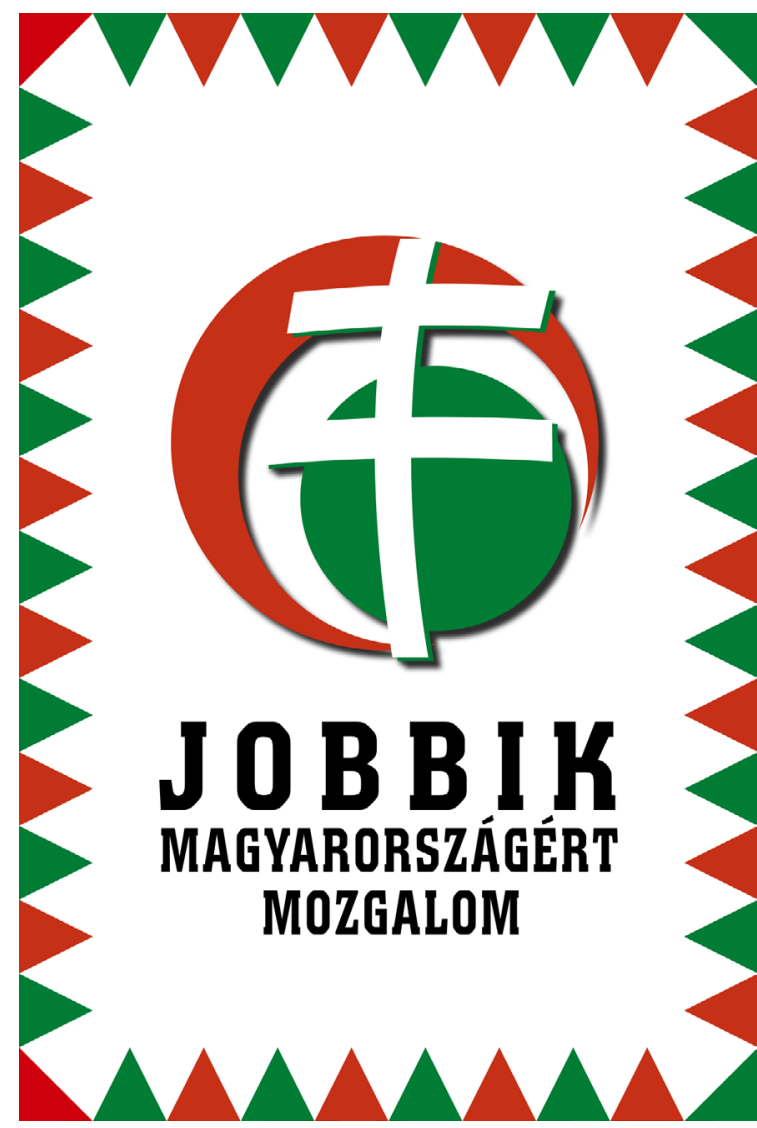

right.
Jobbik was officially founded as a political party in 2003, an outgrowth of the student organization "JobboldaIi Ifjúsági Közösség - Jobbik" (RightWing Youth Association) which was established in 1999, and several other organizations with links to the political right. The young organizers led by Gábor Vona and Dávid Kovács intended to create a new, radical political force that was capable of attracting the masses. They were describing themselves as the answer to a left-wing and right-wing political structure (Pap \& Glied, 2018). Vona, who became party leader in 2006, took the party into an electoral alliance with MIÉP for that year's parliamentary election cycle. The MIÉP-Jobbik Third Way Alliance only garnered 2 percent of the vote and won no seats. As Csurka's MIÉP was dissolved, Vona became one of the most prominent players on the far

On September 17, 2006, when socialist Prime Minister Ferenc Gyurcsany's infamous speech - in which he lied about Hungary's economic situation was leaked to the public, Fidesz, a center-right party, and Jobbik were presented with an opportunity to revive their fortunes. Throughout September and October, a series of demonstrations organized by the members of these two parties demanded the resignation of the PM. Gyurcsany refused to resign and instead resorted to police force. The most violent confrontations between riot police and protesters took place at Freedom Square. Jobbik's vigorous resistance to the intervention made a deep impression on the public. Jobbik, which came to be seen as a party that took the most determined stance against the government, succeeded in shaping its image as an anti-establishment party (Kim, 2016).

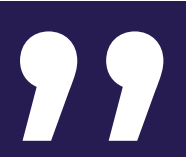

Due to the disillusioning of young people because of a lack of future prospects, deteriorating living conditions, and a frustrating level of state corruption, the popularity of Jobbik skyrocketed among younger voters. Since 2014, Jobbik has consciously tried to address young people that are disappointed with the other parties in Hungary. 


\section{Racist Reincarnation in a Digital Age}

In the next parliamentary election in 2010 , Jobbik enjoyed great success, securing 47 seats, finishing the race as the third largest party with nearly 17 percent of the vote. Jobbik established itself as an essential player in Hungarian politics. In analyzing the electoral success of Jobbik, political scientist András Bíró-Nagy and others focused primarily on the radicalization of the political process and identified three main components of Jobbik's campaign: hostility against minorities, a left-wing economic agenda, and cultural conservatism (Karl, 2017). Mihai Varga has argued that the reasons for Jobbik's success, especially in 2010, lie in its focus on the economy (Varga, 2014). Meanwhile, Gergely Karácsony and Daniel Róna focused on the Roma issue as a motivating factor for Jobbik's voters (Karácsony \& Róna, 2011).

Due to the disillusioning of young people because of a lack of future prospects, deteriorating living conditions, and a frustrating level of state corruption, the popularity of Jobbik skyrocketed among younger voters. Since 2014, Jobbik has consciously tried to address young people that are disappointed with the other parties. As a result of its youth policy, Jobbik's popularity has continued to rise. Especially in the 2014 campaign, Jobbik performed very well among young people, thanks both to the dedication of significant resources and energy by Jobbik as well as extreme right-wing cultural organizations that helped attract youth voters. Jobbik has organized a large number of concerts (featuring national rock bands), festivals, get-togethers, camps, professional forums, and many other youth events (Saltman, 2014). It has become a party which uses its platform and campaign messages to emphasize the problems facing the youth; its youth organization has more Facebook-followers than all other competitors combined (Gregor, 2014).

According to an international survey, conducted in 2016, 53 percent of Hungarians aged between 18 and 35 years would vote for Jobbik (Almássy, 2016). A university survey strengthens the claim that Jobbik is the most active organization amongst youth voters (Róna, 2020). Nevertheless, Jobbik's number of seats in parliament decreased to 23 because of a reform which has decreased the number of parliamentary seats from 386 to 199. So, while Jobbik's seats were cut in half, its overall percentage of the popular vote increased to 20 percent. In April 2015, Jobbik won its first single member constituency, in a by-election following the death of a Fidesz deputy. The seat was won by Lajos Rig, who had a reputation as being an adamant anti-Semite and was rumored to sport an SS tattoo (Murer, 2015). In the April 8, 2018 elections, Jobbik secured 19.06 percent of the vote and became Hungary's second largest party in parliament.

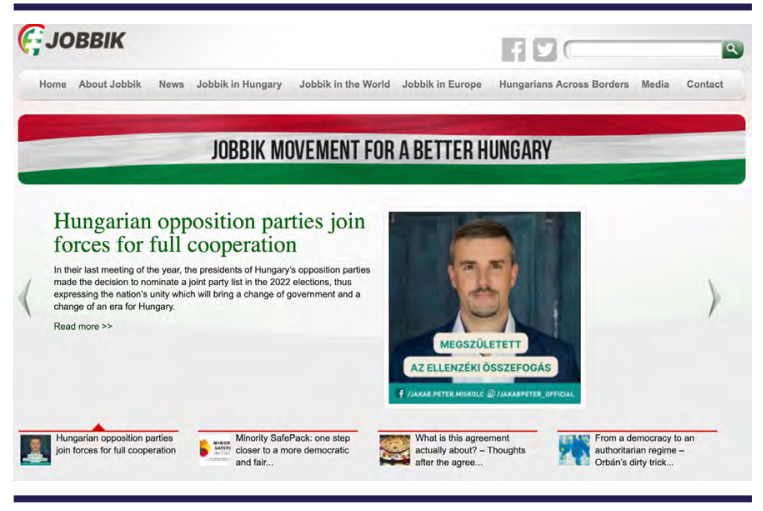

According to Philipp Karl, Jobbik might better be likened to the new social movements of the digital age or to tech-savvy parties such as the German left-wing Piratenpartei than to the traditional radical right. In this context, around 300 websites were identified as parts of the Hungarian radical online network. Researchers also recognized four sub-networks: i) News, media, and history sites; ii) Music and band sites; iii) Web shops; and iv) Political parties and associations. Jobbik has been particularly effective at mobilizing young Hungarians by using online venues to amplify its message, recruit new members, and organize. Jobbik shares some similarities to the new hybrid forms of social movements that developed in the digital age. Manuel Castells emphasizes three paramount conditions for those new movements, all of which apply to Hungary: an active group of jobless academics, a highly developed culture of cyber activism, and the rather widespread use of the Internet. Jobbik's success can be partly explained by its grasp of the influence of 
the Internet and social media on digital natives (Karl, 2017).

Despite adverse allegations, Jobbik has long described itself as "a principled, conservative and radically patriotic Christian party," whose "fundamental purpose" is the protection of "Hungarian values and interests" (Reuters, 2017; politics.hu. 2009). Although the party does not consider itself nationalist but "conservative," this very moderate description is completely different from the way Jobbik is presented in the international media. The party is usually described as "neo-nazi" (Rev, 2015), "far-right," "populist" (Aisch, Pearce, Rousseau, 2016), "neo-fascist" (Chomsky, 2011) and so on. However, in 2014, the Supreme Court of Hungary ruled that Jobbik cannot be deemed "far-right." The party also rejects such labels (Zalan, 2014). What is more, during the Party's 2016 congress, Vona declared that they want to be a "national people's party" (Kowalczyk, 2017).

This political trend, the so-called néppártosodás (transition to a people's party), first emerged before the 2014 parliamentary elections. The party adopted a new style of communication while reversing many radical elements of its earlier program (Csaky, 2016). Jobbik declared that it has turned from a radical right-wing party into a moderate-conservative people's party. Vona, in an interview, promised to "cut the wildlings," the one-time radicals (Jobbik.com, 2015) According to Vona, after 2014 the party has grown out of its "adolescence" and reached its adulthood. Since then Jobbik has significantly changed its views on the EU; internally, the party has started to emphasize opening towards different groups of Hungarian society (Szigeti, 2017). At the same time, Vona distanced the party from "wrong statements" that it had made in the past (Budapost, 2017).

Jobbik had been gaining steam ahead of the 2014 elections, so much so that the ruling party, Fidesz, was forced to raise and discuss elements of Jobbik's agenda. Due to its radical rhetoric, Jobbik attracted 20.69 percent of all votes in the 2014 parliamentary elections and won 23 seats in the National Assembly (Róna, 2016). From the results, the party leadership concluded that its racist and antisemitic rhet-

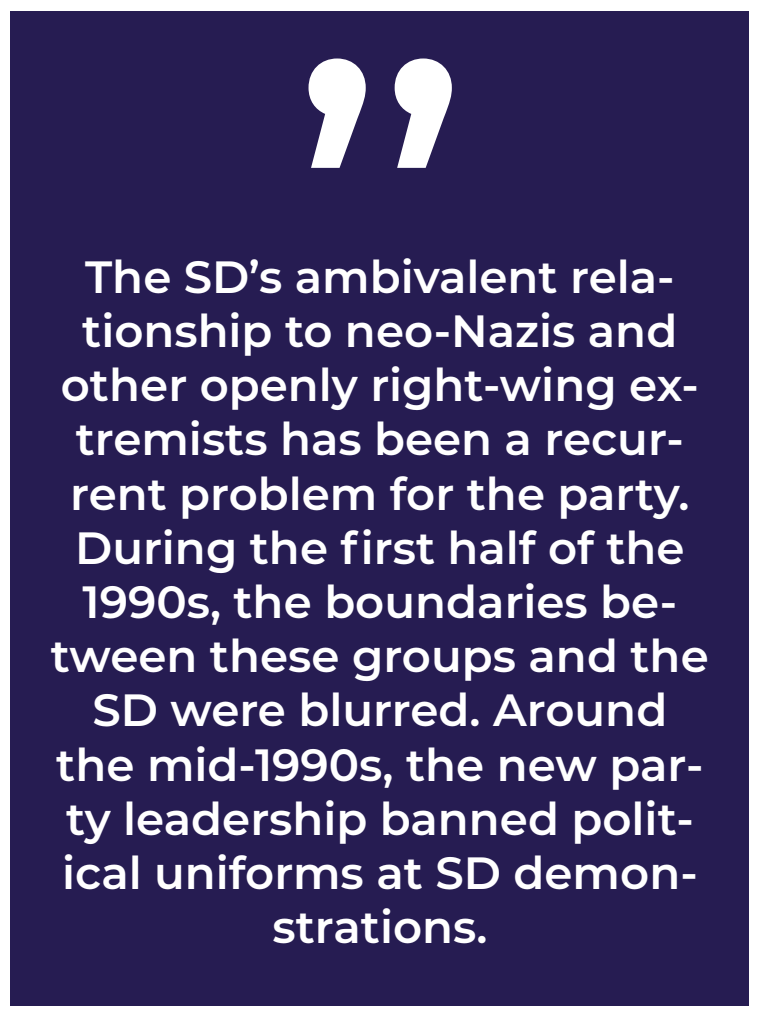

oric should be replaced by a more moderate, yet uncompromising radical political communication with similar objectives - a prerequisite for transforming Jobbik into a popular party. This calculated change earned further support for Jobbik (Pap \& Glied, 2018).

\section{More Than A Political Party t}

Nevertheless, even in its reformed state, Jobbik has always been more than a political party: through their direct actions, such as acts of intimidation and violence, its members engage in physical politics beyond the ballot box. With its stance opposing liberalism, Jobbik has been seen as the new face of illiberal politics in Europe seeking to dismantle the Euopean Union (EU) project (Murer, 2015). The party has also been described as an "antisemitic organization" by The Independentand a "neo-Nazi party" by the president of the European Jewish Congress (Paterson, 2014). However, as Jobbik seeks to increase its electoral support, it looks to convince people that it is capable of governing and to moderate its positions, or at least make them appear more palatable. 
One way of doing this has been the separation of the party's political functions, communications, and allied group activities through the creation of direct-action organs. The symbols, language, rhetoric, and even sartorial choices set Jobbik apart from the direct-action groups. For instance, the party chairman wears a suit; the direct-action network members often do not (Murer, 2015).

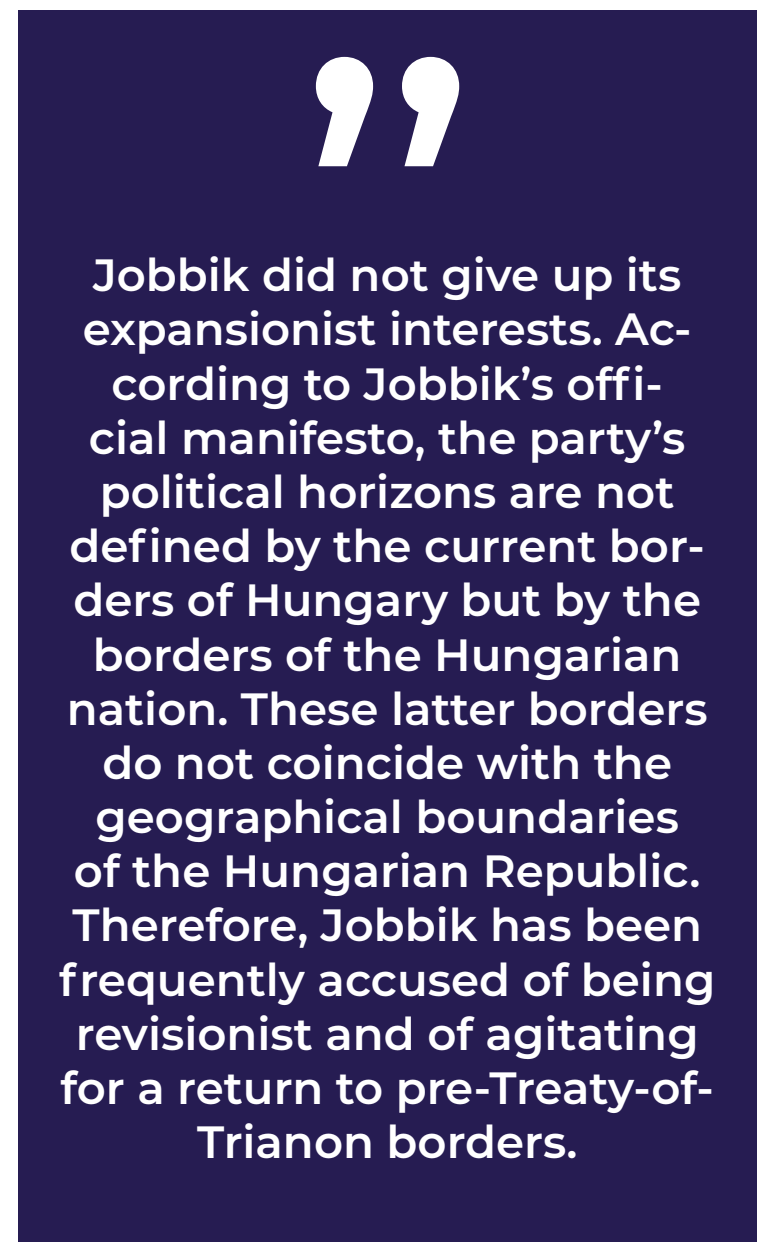

Eventually, the party started to re-define itself as a conservative people's party. According to the party's manifesto on the guidelines of a future government, Jobbik represents all Hungarian citizens and people and aims to build a modern national identity, while rejecting the chauvinism of the 20th century (jobbik.com). Analyzing an opinion poll conducted for Euronews in Feb. 2020, leading political scientist Balázs Böcskei commented that Jobbik has completed its transformation into a centrist people's party and its voting base has been changed; now, it is a predominantly moderate pro-EU constituency.
Is that really so?

Jobbik did not give up its expansionist interests. According to Jobbik's official manifesto, the party's political horizons are not defined by the current borders of Hungary but by the borders of the Hungarian nation. These latter borders do not coincide with the geographical boundaries of the Hungarian Republic, given that the Hungarian nation had its contiguity dismembered by "the imposition of the Trianon peace diktat." The manifesto says: "Our fundamental principles are: thinking in terms of a nation of 15 million, establishing 'protective power' status for the motherland vis-à-vis Hungarian communities beyond the border, the cultural and economic reunification of the Hungarian nation, the granting of Hungarian citizenry to every Hungarian, the establishment of a Ministry of National Affairs, the promotion of efforts for self-determination, the reincorporation of beyond-the-border communities and émigrés into active Hungarian life, the promotion and development of border-transcending regional cooperation; and the coordinated development of domestic relationships between disparate nationalities... We will also develop a legal defense network, which will extend assistance to Hungarians living in cleaved territories, should their individual or collective rights be abused..." (Guide, 2010).

Because of this stance, Jobbik has been frequently accused of being revisionist and of agitating for a return to pre-Treaty-of-Trianon borders (Zimberg, 2013). However, Jobbik has never suggested changing borders by force and believes that the ultimate solution is territorial and cultural autonomy within an EU framework of minority rights (Daily News Hungary, 2017). It is a fact that one-fourth of ethnic Hungarians live outside the country (Inder Singh, 2000). Many suffer discrimination because of their ethnicity, causing frequent diplomatic disputes between Hungary and its neighbors. Jobbik dedicates itself to supporting the cause of Hungarian minorities in adjoining countries (Molnar, 2001 \& Frucht, 2005). On the other hand, Jobbik considers its most important task to be the reunification of a Hungarian nation unjustly torn apart during the course of the 20th century: "It is our most fundamental moral duty to 


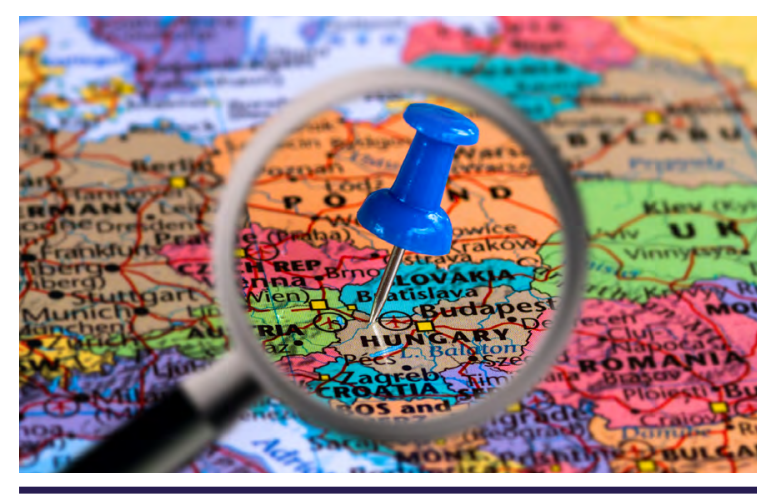

represent the interests and defend the rights of Hungarian communities. We will strive, perpetually, for the collective rights of the Hungarians of the Carpathian basin, and for the realization of their territorial, economic and cultural self-determination" (Guide, 2010).

Jobbik was among the founding members of the Alliance of European National Movements (AENM), alongside the French National Front, the Ukrainian Svoboda, Italy's Tricolour Flame, the British National Party, the Swedish Democrats, the Finnish Blue and White Front, the Portuguese National Renovator Party, and the Spanish Republican Social Movement. AENM was formed in Budapest on October 24, 2009. Jobbik's membership ended in February 2016, when the party cut its affiliation with AENM. However, Jobbik currently has ties to the Conservative People's Party of Estonia, the Bulgarian United Patriots, the Latvian National Alliance, the Polish National Movement, the Indian Bharatiya Janata Party, the Russian Rodina, and the Turkish Nationalist Movement Party. Jobbik proposed joining the European People's Party, but was rejected in August 2018 (Murer, 2015).

When the popularity of the ruling party declined dramatically due to major corruption scandals involving the government and Orban's family in early 2015 , voters started shifting toward Jobbik, which is the only serious opposition to Orban's government and has been moralizing about anticorruption policies and defending the rights and interests of what they call true-born Hungarians (Rev, 2015). To capitalize on the opportunity, Jobbik adopted a policy of penal populism and promised to bring political crime to an end. The party argued that the national police should be greatly strengthened and promised to restore the death penalty if they came to power (BBC News, 2015 \& Daily News Hungary, 2015).

Stating that the image of the political profession has been almost irreparably damaged, Jobbik's party manifesto also underlined that, "In Hungary the word 'politician' is now synonymous with the word 'scoundrel.' A fish rots from the head down; which is why circumstances of decency must first be produced in the country's leadership... Our goal is not merely the abolition of corruption, it is rather the cessation of the existence of politicians as lawmakers - as being above the law... Jobbik wants the holding to account of politicians to be all-encompassing... It is high time that political crimes finally become classified under the Hungarian penal code!" (Guide, 2010).

In 2016, the party pursued its strategy of refurbishment by abandoning parts of its original ideological corpus and excluding certain extremist elements, in order to make its image more respectable and to craft a credible opposition to the government of Orbán (Thorpe, 2016). In summer of 2016, Vona declared a new style of politics, called "modern conservatism" with the aim to exceed the pointless debates between the right- and the left-wing and to induce cooperation among Hungarians with different political backgrounds. According to Vona, the goal of "modern conservatism" is, beyond politics, to build a society that can, by its proactivity, be a basis for a more democratic political functioning. As a historical precedent, he referred to the ideals of István Széchenyi, who is considered as one of the greatest statesmen of Hungarian history (Dunai, 2017). Despite Jobbik's pledges, particularly to the Jewish community in Hungary, many left-wing intellectuals and political figures say they want to keep their distance from an organization often deemed undemocratic. Thanks to these changes, some media now debate whether Jobbik should be classified as "far right" (McLaughlin, 2017).

Following the 2018 parliamentary election, Gábor Vona resigned due to his earlier promises that he would resign if he could not lead the party to victory. Despite rumors that Jobbik would change its policies, the National Board of the party unan- 
imously decided in favor of the moderate right-wing conservative platform. On May 12, 2018, the party elected Tamás Sneider as the president and Márton Gyöngyösi as the executive vice president of the party. The Hungarian press evaluated the new presidency as a victory of the moderate politicians. Sneider told he wanted to build a socially conscious party based on the teachings of Christianity 


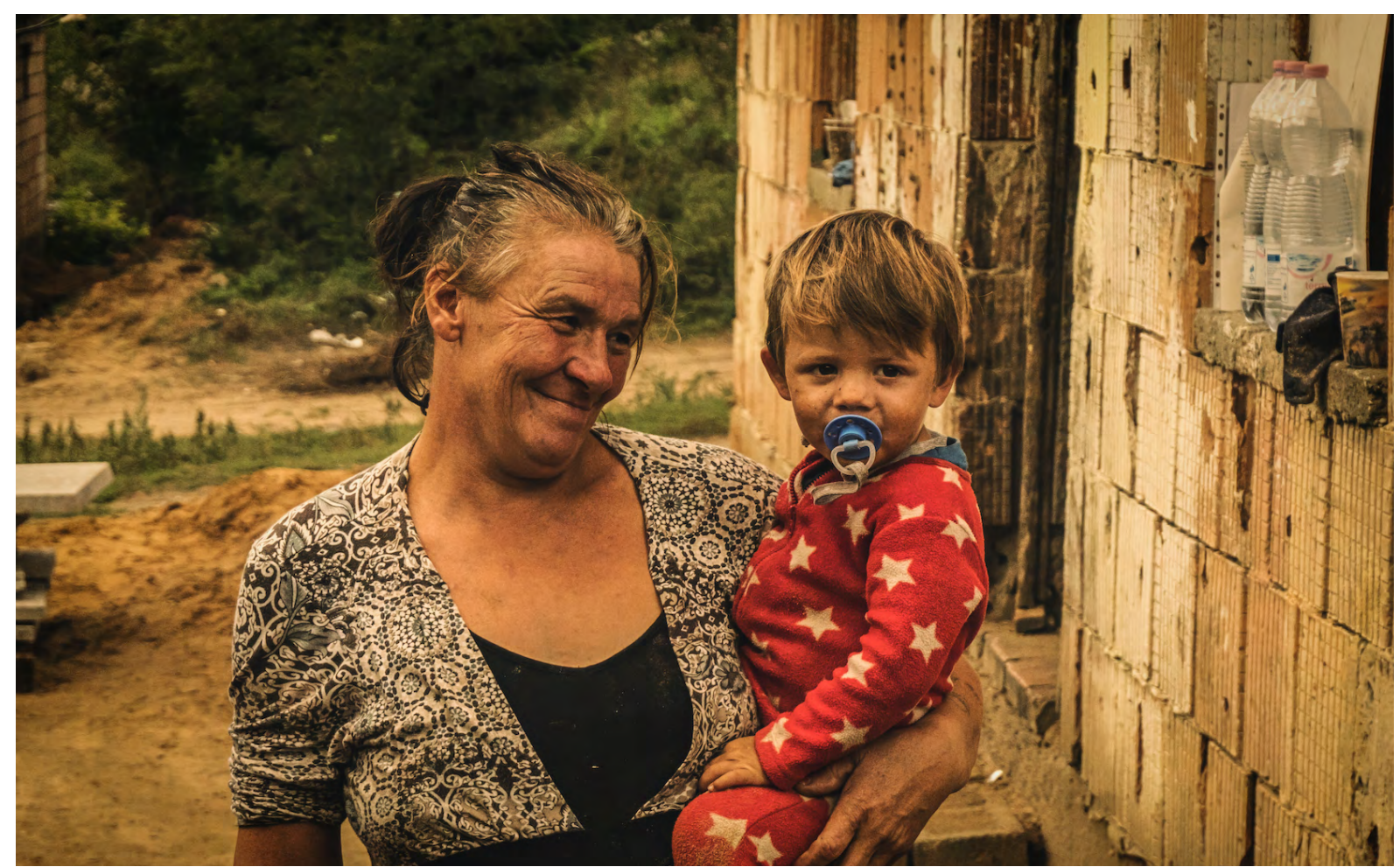

Woman and her son in a Roma settlement in Hungary. 40 kms from Budapest there's a really poor gipsy settlement called Bag.

\section{Jobbik vs. Roma People}

Tension between the Roma and the non-Roma population is a longstanding and pervasive issue in Hungary (Halasz, 2009). There is a high level of social prejudice against the Roma community as reported by Amnesty International (AI, 2014), and Jobbik has capitalized on this particular issue for its own political ends. Along with antisemitism, xenophobia, and racism, anti-Roma sentiments presaged the rise of the far right in Hungary. Putting aside political correctness and airing anti-Roma views rapidly increased Jobbik's popularity, especially in the eastern regions of Hungary, where - apart from the big cities - the majority of the Roma population lives (Pap \& Glied, 2018). When Jobbik took up the case of a murder committed by members of the Roma community, Roma crime and penal populism advanced to the political forefront (Kim, 2016).

On October 15, 2006, a group of Roma people lynched a Hungarian teacher in the Eastern Hungarian village of Olasz- liszka (Politics, 2009). When a Tiszavasvari teacher, Lajos Szögi, drove through Olaszliszka, an accident occurred in which Szögi knocked down a Romani girl. Szögi got out of his vehicle to check whether or not the girl was seriously injured. Although the girl was not harmed, the onlookers misinterpreted the scene and a group of angry Roma villagers beat Szögi to death, while his own children, who had been travelling with him, looked on from the car. This grim news spread quickly across the country, and those who interpreted the incident as a serious threat to their own security asked for protection from the authorities. Investigation into the case required time; however, Jobbik thought that the authorities were too slow to react to the potential threats from the Roma community (Kim, 2016). The case turned public attention to the failure of Roma integration and the inability of the Hungarian police to maintain law and order in the Hungarian countryside (Murer, 2015).

Jobbik's leaders and members did not hesitate to exploit the incident and were intent upon addressing "Roma crime" in their own way. Jobbik formulated its first response: "The Movement for a Better Hungary took charge as the only party to 


\section{9}

Jobbik argues that Roma people are genetically predisposed to criminal activity. With this in mind, Jobbik took a concrete course of action to tackle the alleged "Roma crime". The idea of setting up a "national guard" became widespread among Hungary's radical-right political parties. On August 25, 2007, Jobbik founded the Hungarian Guard (Magyar Garda) as a direct-action organization to fulfill the role of policing the Roma.

face one of the underlying problems in Hungarian society, the unresolved situation of the ever-growing gypsy population. The Movement spoke up about, what everyone knows but others do not say due to political correctness, the phenomenon of 'gypsy crime' is real. It is a unique form of delinquency, different from the crimes of the majority in nature and force" (Halasz, 2009).

The implication was obvious. Jobbik argued that Roma people were genetically predisposed to criminal activity. With this in mind, Jobbik prepared a concrete course of action to tackle the alleged "Roma crime" (Kim, 2016). The idea of setting up a "national guard" became widespread among Hungary's radical-right political parties. On August 25, 2007, with the blessing of his party, Vona founded the Hungarian Guard (Magyar Garda) with a mass loyalty oath ceremony at Saint Gyorgy Square (Pal, 2007; Murer, 2015 \& Jordan, 2010)) as a direct-action organization to fulfill the role of policing the Roma with the alleged intent to "strengthen national self-defense."
Jobbik claimed that the aim is to assist in "maintaining public order" and "self-help in case of natural disasters, and humanitarian interventions" (Varga, 2014). Yet the appearance of the Guard, whose members were uniformed in black with the red-and-white Arpad Stripe emblem on the front, was reminiscent of the pro-Nazi Hungarian Arrow Cross party (Jordan, 2010). Inspired by the Guard, other similar quasi-paramilitary organizations were also formed, and the Hungarian Guard Movement became increasingly popular and visible across the country (Kim, 2016). According to many academics, it is the Guard that made a significant contribution to Jobbik's success. (Karacsony and Rona, 2010). However, the Metropolitan Court of Budapest disbanded Magyar Gárda in 2009. Later, the Hungarian Supreme Court approved the court decision, and, in an appeal trial, the ECtHR adjudicated on the case in July 2013 and upheld the ruling of the Hungarian Supreme Court. (Ivanis et al., 2014).

It did not take much time for the group to reorganize under at least three banners, as the Új Magyar Gárda (New Hungarian Guard), the Magyar Nemzeti Gárda (Hungarian National Guard), and the Szebb Jövoért Polgáror Egyesület (Civil Guard Association for a Better Hungarian Future). Szebb Jövoért is the most active of the three and has its roots in paramilitary organizations from the inter-war period and WWII. These groups work together and with Jobbik (Murer, 2015). In 2019, László Toroczkai, the president of the Our Homeland Movement, who was expelled from Jobbik, reorganized the Magyar Gárda. Nowadays, Magyar Gárda belongs to this movement.

In August 2012, members of The New Hungarian Guard, Magyar Nemzeti Gárda, Szebb Jövoért Polgáror Egyesület, Betyársereg (the Outlaws' Army), Magyar Nemzeti Arcvonal (the Hungarian National Front), and Védero (Defence) gathered at the small village of Devecser to demonstrate against "gypsy crime (cigánybunozés)." The demonstration began with a welcome from the Jobbik affiliated Veszprém county chairman, Gábor Ferenczi, who told the crowd that "self-defense is a fundamental right." The "self-defense" was for ethnic Hungarians 
and so-called Hungarian "values" only, which by definition the Roma residents of Devecser do not hold (Murer, 2015). Zsolt Tyirityán, the leader of the Betyársereg, stated that "I will use any means necessary to protect our race. I am a racist and I am proud of it, because I love my race and I'm going to defend it." The demonstrators then began throwing bottles and rocks at homes they believed to belong to Roma and shouting, "You are going to die here" (Hungarian Spectrum, 2013). This was no idle threat, as the events in Devecser resembled those the year before in the small village of Gyöngyöspata, in Hungary's northeast corner (Murer, 2015).

In March-April 2011, elements of these far-right direct-action groups descended upon Gyöngyöspata and decided that they would run "military exercises" and walk "security patrols" to defend the residents against crime. Védero announced that it was going to establish a paramilitary training center in the Roma section of town (BBC News, 2011). As the police had done nothing to stop the incursions by the paramilitary groups, an American businessman, with assistance from the Hungarian Red Cross, organized the evacuation of around 270 Roma women and children from the beleaguered village (Der Spiegel, 2011). The village became such a focal point for tensions between far-right militants and the Roma community that the Hungarian National Front (MNA) published on their web page that they believe the confrontations in Gyöngyöspata were the "outbreak of a cleansing civil war." Since then, the MNA has held monthly paramilitary exercises either at their headquarters on a former Soviet military base outside of Bony or in other cities all around the country. These groups coordinate with one another and organize training exercises not only for other Hungarian groups, but for groups across the region. The MNA does this because, according to their propaganda materials, they believe that civil war is imminent (Murer 2015).

In the logic of the Jobbik-affiliated, direct-action groups, and within the rhetoric of Jobbik itself, Jews and Roma become two sides of the same threatening coin. For the extreme right, and increasingly for more politically mainstream Hun- garians, a shared fantasy of small-scale crimes by Roma is allied with conspiracy theories concerning large-scale financial crimes perpetrated by bankers and the EU. In this paranoid fantasy, both must be violently opposed. Moreover, just as Roma are habitually associated with the commission of petty crime, larger financial degradations associated with globalization and capitalism are often attributed to Jews. This combination could be seen in a December 2012 propaganda campaign from the MNA, which claimed "...a virtual bulldozer is destroying our country. The blade of the bulldozer is made up of gypsy criminals and its driver, who is directing the whole process, is the Zionist Jewry" (Murer, 2015).

The connection between Vona/Jobbik and Zsolt Tyirityán and his Betyársereg was exposed during a campaign rally in February 2014, held by Jobbik in a former synagogue that became Esztergom's civic hall during the communist period. Vona and Jobbik wanted to hold the event there to demonstrate that that "true Hungarians" could go anywhere and say anything, including discussing the "evils of capitalism" in a former synagogue. While Vona addressed the 200 or so Jobbik supporters inside, Tyirityán's Betyársereg provided "security" to defend the Jobbik speakers against the nearly 100 demonstrators who protested outside, some with yellow Stars of David pinned to their chests (Aljazeera, 2014 \& Murer, 2015). Similarly, Tyirityán declared at a November 2013 anti-Roma demonstration in Vác, that people "should stop being the prey and start being the predators" vis-à-vis Roma (Murer, 2015).

In 2009, Betyársereg and Jobbik signed a cooperation agreement, saying that "we support each other and take part in each other's events." While Betyársereg does not receive funds directly from Jobbik, it did have access to more than 40 million forint (approximately Euro 130,000) provided by the Jobbik Party Foundation to the Sixty-Four Counties Youth Movement. Tamás Sneider, then vice president of Jobbik, stated that the relationship between Betyársereg and Jobbik "must be acknowledged to be a division of labor. It's good to have an Outlaw's Army; it's nice to have the Sixty-Four Counties because 
they are able to do what I cannot from inside parliament" (Murer, 2015).

The relationship between Jobbik and the radical nationalist Betyársereg has caused much controversy. Betyársereg openly asserts that elements of guerrilla warfare, such as preparing explosives and training for acts of terrorism, can be learnt from the propaganda videos of Al-Qaeda and ISIS. With varying degrees of success, Jobbik has tried to demonstrate its distance from radical organizations since 2015 (Pap \& Glied, 2018). The separation between Jobbik and the direct-action groups allows the party itself to suggest that it is more moderate, without actually alienating the participants in the direct-action groups. The separation also allows Jobbik to claim that it does not endorse violence in any way. Jobbik told Reuters through a communiqué that "Jobbik condemns violence, and its members cannot be linked to such acts either" (Goettig \& Lowe, 2014).

Jobbik's anti-Roma character does not consist solely of direct-action groups. In 2015, deputy leader Előd Novák posted on Facebook a picture of himself and his family next to a separate image of the first newborn in Hungary of the year, who was born to a Romani family. In a comment on the pictures, he stated that the population of Hungarians would become a minority and suggested that the Romani population is the biggest problem facing Hungary. Novák's remarks were both condemned and supported. Novák would later respond to the issue by refusing to apologize and suggested that the family should apologize to him (Thorpe, 2015). Novák was forced by the party's parliamentary group to resign from his position as an MP in 2016 (Székely, 2016).

Prior to Jobbik's entry onto Hungary's political stage, parties had not dealt openly with the Roma issue and instead treated it as a part of wider social problems arising from underlying social circumstances such as the prevalence of extreme poverty and illiteracy. In contrast, Jobbik approached the issue by taking an exclusively "ethno-perspective," promulgating the view that "most of gypsy society lives outside the law and outside work and education" (Bíro-Nagy et al., 2012), and this was the cause of perceived "Roma criminality."

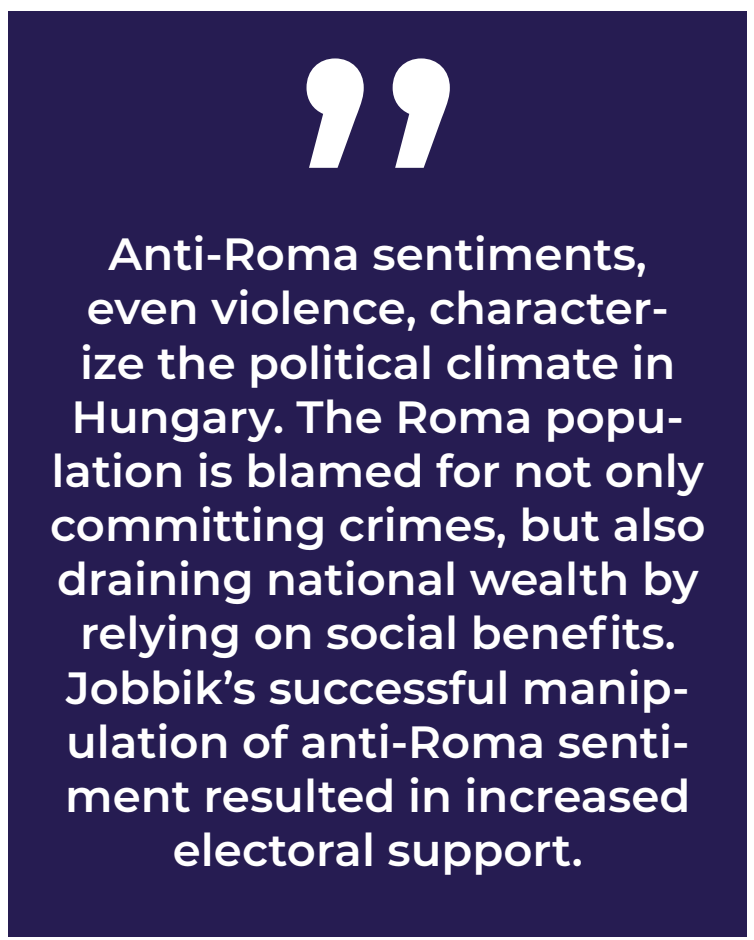

The significance of this socio-cultural phenomenon for shaping the party identity is well observed by political analyst Andras Bíro-Nagy, who notes that: "Anti-Roma sentiment is very strong in Hungarian society. It is Jobbik that made the most use of this social attitude for its own benefit, and was indeed successful... For that process, I stress the role of the Hungarian Guard. The Guard was the paramilitary arm of Jobbik and it was very important for the party to reach many people via media. With the Guard, Jobbik could appear in every corner of the country, precisely in the 'crisis area' of Northeast Hungary. This is the poorest region of the country, in which ethnic conflicts are recurrent and Jobbik, along with the Guard, marched there on a regular basis. When people saw it, they said, "finally there is someone who creates order and keeps [people] safe from potential threats in this abandoned under-served rural area.' In this way, Jobbik could garner support" (Kim, 2016).

Jobbik's successful manipulation of anti-Roma sentiment resulted in increased electoral support. Jobbik distinguished itself from other political groups by finding its own practical solution. According to Laszlo Lengyel, a leading political 
commentator at the Financial Research Institute, this differentiated approach of Jobbik is well observed at the small town of Pecs. This is where a boy was raped and murdered on a roadside leading to a predominantly Roma area. According to Lengyel, immediately after the incident, Vona, went to the crime scene and spoke in front of several hundred people. He encouraged people to treat the Roma in a certain way. He said that "there are people around here who might kill our wives, our children, and our mothers." Following this incident, the people in Pecs felt the need to place the Roma community under police surveillance and to prevent them from leaving the Roma area of town (Kim, 2016). By basing their campaign on the Roma crime issue, Jobbik made electoral gains, and its use of anti-Roma political rhetoric was instrumental in shaping party identity.

Likewise, anti-Roma sentiments, even violence, also characterize the current political climate. These expressions of antagonistic politics are tied to the widely held political belief among the political right that Hungary is under assault from outside forces, whether expressed as international global capitalism, dominated by Jews, or trans-local, "rootless" Roma painted as the perpetrators of "gypsy crime" (Murer, 2015). The Roma population is blamed for not only committing crimes, but also draining national wealth by relying on social benefits. This anti-Roma attitude was well demonstrated by a social survey conducted by social researchers at the Tarki institute. They found that more than two-fifth of respondents (40 percent) were in favor of taking discriminatory measures against the Roma community (Bernath, Juhász, Krekó \& Molnár, 2013).

Jobbik's 2010 electoral manifesto explicitly stated that the coexistence and cohesion of Magyar and Roma is one of the severest problems facing Hungarian society. "On the occasion of 1989's regime change, great swathes of the Gypsy people lost their jobs; who subsequently found themselves unable, and in many cases unfortunately unwilling, to adapt to the new realities... In certain parts of the country over the last decades the situation has deteriorated to truly deplorable levels. Generations have now grown up, having never once seen their parents in work. The continuation of the Gypsy people's circumstances along their current course is nothing short of a potential time-bomb, and if it is not subject to concerted intervention, our mutual home could sink into a state of virtual civil war. At the present time a segment of the Gypsy community strives for neither integration, nor employment, nor education; and wish only that society maintain them through the unconditional provision of state benefits" (Guide, 2010).

The manifesto continued: "The most pressing of these issues is undeniably the halting of gypsy crime, for which the strengthening of the established police, and the foundation of a dedicated rural police service, or Gendarmerie, is required... certain specific criminological phenomena are predominantly and overwhelmingly associated with this minority, and that as a result such phenomena require the application of fitting and appropriate remedies. Law enforcement initiatives therefore must go hand in hand with the reform of social, educational and employment policy, given that Gypsy integration means assimilation into society-at-large, and that this process must commence at school, even in nursery school..." (Guide, 2010). 


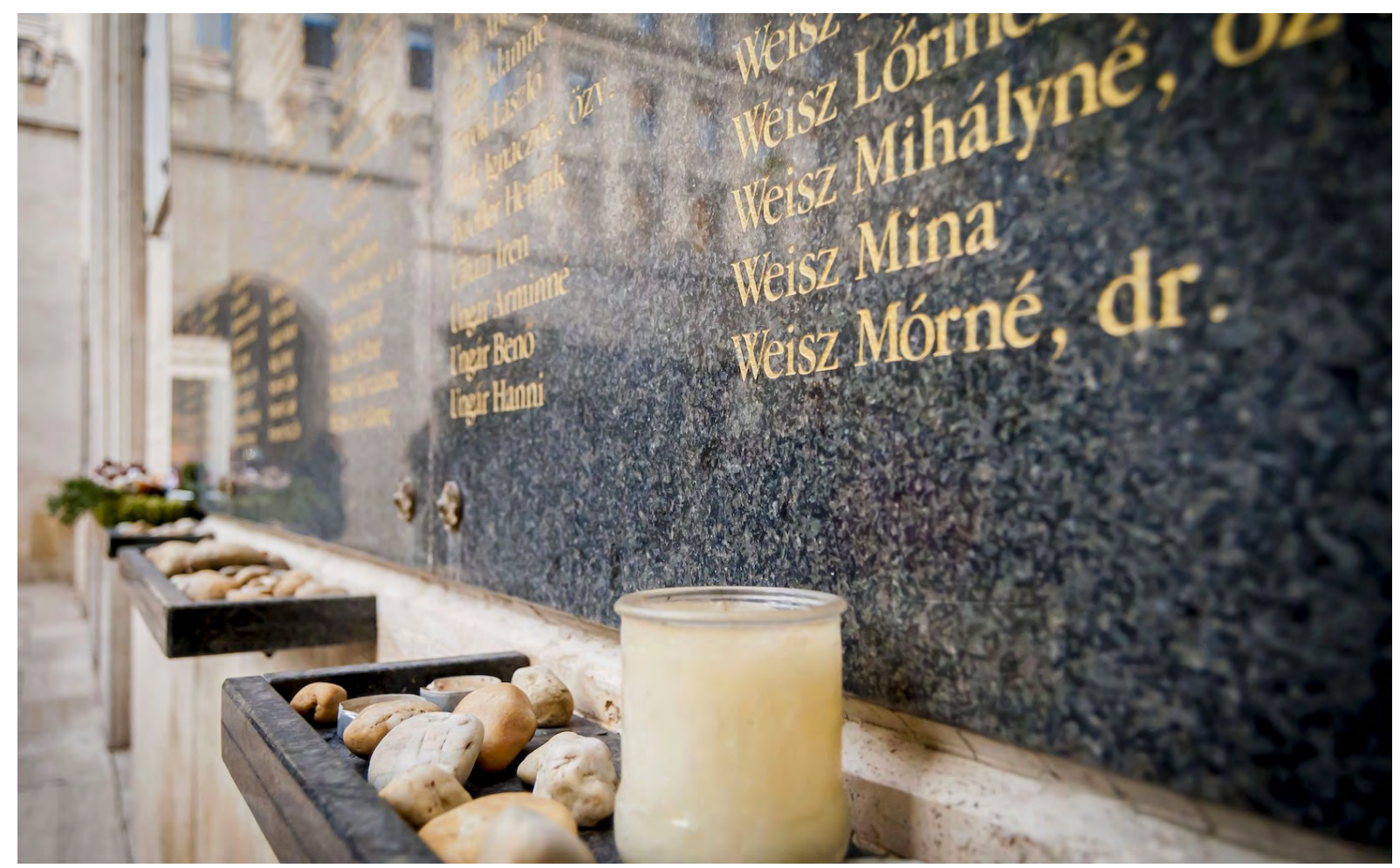

The memorial wall with the names of the members of the Hungarian Jewish community perished in the Holocaust, inside the famous Dohány Street Synagogue.

\section{Antisemitism and Hungarism}

Another element that has contributed to Jobbik's rise is that of Hungary's specific history of antisemitism and its embedded socio-cultural prejudice towards Jews. Unfortunately, in contemporary Hungary, antisemitism remains a very public part of the political landscape (Murer, 2015). In the context of post-1989 political developments, antisemitism - like anti-Roma sentiment - is essentially linked to the far right. Being anti-Roma was the main platform of MIÉP, whereas antisemitism is the central tenet of Jobbik's political rhetoric. A poll on antisemitism, conducted by the Anti-Defamation League (ADL), suggested that a large segment of the Hungarian population thought that Jews wielded too much influence in global financial markets (63 percent), and that they were utilizing this influence to serve their own interests (57 percent) (Kim, 2016).

Despite this subtle difference, both MIÉP and Jobbik have represented an extreme ethno-nationalism, the essence of which was expressed through a notion of their own creation: the value of Hungarianness (Kim, 2016). Hungarianness, or Hungarism, is also a powerful Jobbik phenomena. Established in the 1930s, Hungarism is one of the ideologies of the traditional Hungarian far right. Its ideas were sustained by émigré groups after 1945, and it returned to Hungary after the transition to democracy. Two small groups operate independently from each other: the Hungarian National Front (Magyar Nemzeti Arcvonal) and the Pax-Hungarica Movement (Pax Hungarica Mozgalom). Neither has become a significant political actor, but their members and supporters generally vote for right-wing parties. Their messages are anti-Western, antisemitic, anti-capitalist, and anti-democratic, with an added emphasis on maintaining military capabilities (Pap \& Glied, 2018).

Although the term "Hungarism" was coined by the Catholic bishop Ottokár Prohászka to describe an ideology rapidly spreading before World War II, the Hungarist ideology has no strong Christian influence. During the last two decades, the foreign policy stance by these two organizations has taken on a significant pro-Russia orientation, which aims to build economic and cultural relation- 
ships with Russia. Although Jobbik is not an outgrowth of traditional Hungarism, both movements share some ideological elements (antisemitism and a Russian orientation), and both also typically use the so-called Árpád striped flag (Pap \& Glied, 2018). According to Jobbik, Hungarianness ought to be safeguarded from perceived "foreign" influences. With this in mind, any supranational bodies, international organizations, or multi-national companies were seen as alien to the national interest (Kim, 2016).

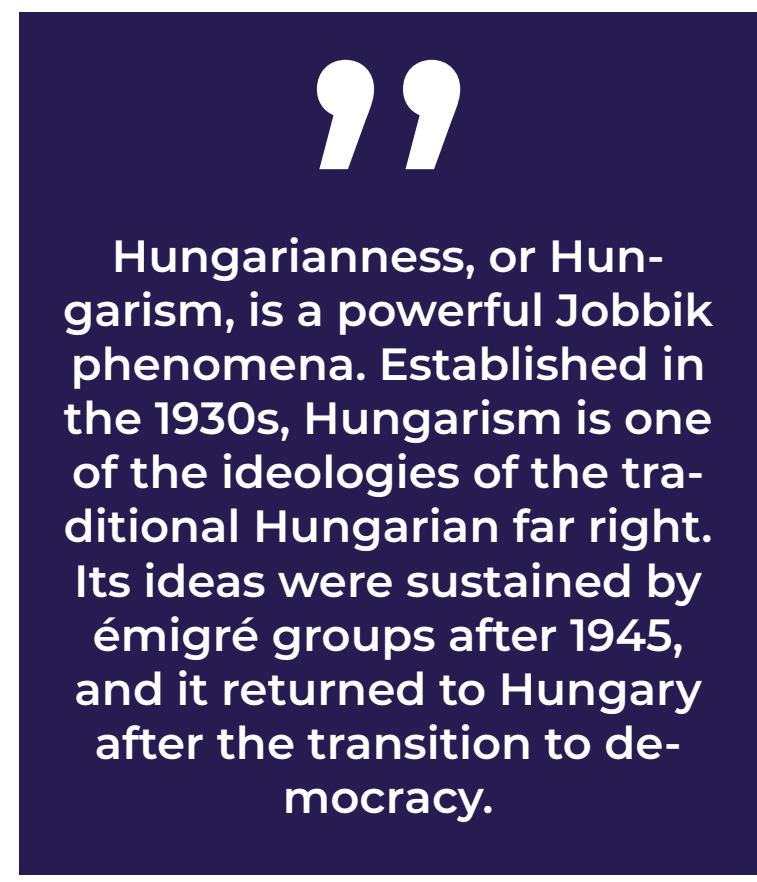

Jobbik's transformation since 2014 is a unique post-transitional political development that is rooted in elements of Hungarian nationalism. These national elements included underlying social prejudice against Roma and Jews, a preference for paternalistic economic systems, and a re-introduction of a historical narrative based in mythic Turanism. Jobbik has capitalized on these elements in order to shape party identity, and their political maneuvering has proved effective, recognizably influencing both politics and society as a whole (Kim, 2016).

Despite the fact that Jobbik lead- ers have suggested registration of the Jews in Hungary (Stephens, 2017), the party has strenuously denied allegations of antisemitism (LeBor, 2009) or racism, claiming such allegations are either politically motivated (Moore, 2008) or simply false. It has also dismissed the criticism of perceived antisemitism, racism, and homophobia as the "favorite topics" of its political opponents. Even so, the movement has been accused of playing on those fears (Freeman, 2009). For instance, in a newsletter published by a group calling itself "The trade union of Hungarian police officers prepared for action," the following was printed: "Given our current situation, antisemitism is not just our right, but it is the duty of every Hungarian homeland lover, and we must prepare for armed battle against the Jews." The editor of the union, Judit Szima, was a Jobbik candidate in the upcoming election for the EU Parliament. Haaretz alleged Szima "didn't see anything wrong with the content of the article" (Lahav, 2009).

In spring 2012, a Jobbik deputy in Hungarian parliament, Zsolt Baráth, caused outrage by commemorating the 1882 blood libel against Jews in Parliament. The Tiszaeszlár blood libel, found later to be unrelated to Jews, was known as the first major anti-Jewish event in modern Hungary, predating the Holocaust (Free Hungary, 2012). After the incident, Baráth was not re-elected and is no longer an MP. In November 2012, while evaluating the latest news on the controversial Israeli military action in the Gaza strip, Jobbik's deputy parliamentary leader, Márton 
Gyöngyösi, stated in his speech at Parliament, "I think such a conflict makes it timely to tally up people of Jewish ancestry who live here, especially in the Hungarian Parliament and the Hungarian government, who, indeed, pose a national security risk to Hungary" (Ynetnews.com, 2012). Around 10,000 Hungarians (Than, 2012) in Budapest protested against Gyöngyösi's antisemitic remarks. All major Hungarian political parties took part in the protest. Jewish organizations responded to Gyöngyösi's speech by describing it as a reintroduction of Nazism in the Hungarian Parliament and by describing Jobbik as a Nazi party. Gyöngyösi admitted immediately after his speech that he had composed his sentence wrongly and offered an apology (Al Jazeera, 2012).

On May 4, 2013, Jobbik members protested against the World Jewish Congress in Budapest, claiming the protest was against "a Jewish attempt to buy up Hungary" (BBC News, 2013). Jobbik MP Enikő Hegedüs vociferously condemned both Israel and Jews at the rally as her husband, Lóránt Hegedús Jr., stood nearby (Heneghan, 2013). An ordained minister in the Reformed Church in Hungary, Lóránt Hegedüs himself had served in the National Assembly as an MP of the far-right nationalist Hungarian Justice and Life Party from 1998 to 2002. He invited Holocaust denier David Irving to his Budapest church in 2007 as a "special guest" (Odehnal, 2011) and has also been accused of antisemitism on several occasions for statements he has made about Jews at Jobbik events.
In 2014, Tibor Ágoston, the deputy chairman of Jobbik's Debrecen and Hajdú-Bihar County organization, referred to the Holocaust as the "holoscam" (politics.hu, 2014). Then-Jobbik leader Vona later stated that he had criticized Zionism as a political idea and pointed out that he understood the Hungarian Jewish community had to survive traumas during the 20th century that make dialogue very hard. At the same time, he emphasized that he wanted to have harmonic relations with the Hungarian Jewish community (Bayer, 2017).

\section{According to a survey on an-} tisemitic prejudices, antisemitic political discourses, and political antisemitism in Hungary, 10-15 percent of the Hungarian adult population held a strong antisemitic prejudice. Surveys conducted after 2006 show not only an increase in the absolute percentage of antisemites, but also an increase in the proportion of antisemites who embed their antisemitism in a political context. This phenomenon is directly linked with the appearance on the political scene of Jobbik as an antisemitic party. When examining the causes of antisemitism, the most interesting finding was that the strength of antisemitic feelings is regionally different and that these differences correlate with the strength of Jobbik's support across various regions. Accordingly, the support for a far-right party is not a consequence of antisemitism, but conversely the party should be regarded as a factor that mobilizes attitudes leading to antisemitism. Thus, antisemitism is a consequence of an attraction to the far-right rather than an expla- 
nation for it (Kovacs, 2012). Later surveys have also showed that anti-Jewish sentiment is reactive to political campaigns: antisemitism increased in election years and then fell back to its previous level. (Karacsony \& Rona, 2010).

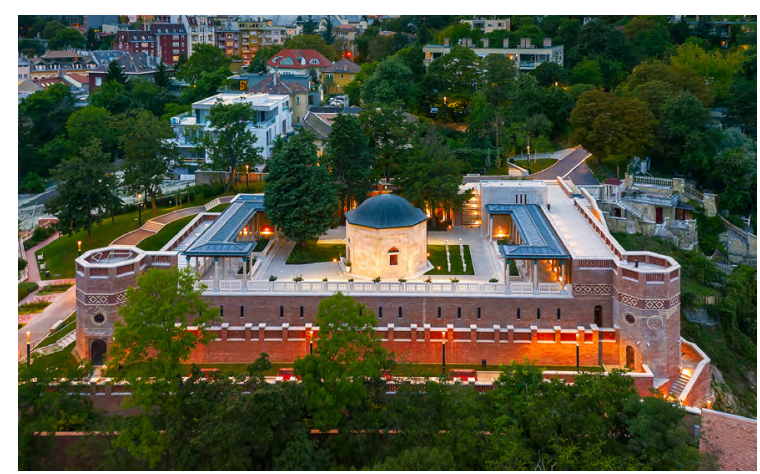

Aerial view from Tomb of Gul Baba, Turkish memorial monument in Budapest, Hungary.

\section{Unique Among Euro- pean Racists: An Islam-friendly Jobbik}

Although they differ regarding the extent and form of action demanded, the agenda of each far-right party includes the fight against the spread of Islam in Europe, primarily manifested by halting the construction of mosques. Far-right parties demand governments take radical measures to force immigrants, predominantly from Muslim-majority countries, to accept

European traditions, customs, and legal order; as well as the forced learning of the language of the host country. In many ways Jobbik is similar to other far-right groups in Europe; however, it is alone among radical parties in Europe in pursuing a Muslim-friendly policy (Pap \& Glied, 2018). Jobbik's views on Islam differ significantly from those of most parties in Europe that are recognized as nationalist, which consider Muslim people as a serious threat to the safety and the identity of Europe (Kowalczyk, 2017).
Perhaps, the main reason for this is the fact that in Central and Eastern Europe (CEE), immigration has not caused problems that affect people's daily lives. There are no major immigrant groups; religiously active citizens are typically Christian, and cultural identity is based on Judeo-Christian cultural traditions. This is exactly why the nationalistic radical rhetoric of Jobbik is outstanding and controversial at the same time: its former leader, Gábor Vona, considers Islam humanity's last hope. Moreover, Muslim migrants were not targeted in Hungary as they have been in other parts of Europe, where many far-right movements overtly define Muslim immigrants as an existential threat. Since Hungary has no sizeable Muslim community but a rapidly increasing Roma population, the social and political issues typically linked to Muslims in Western Europe have been linked instead to the Roma (Pap \& Glied, 2018).

The Hungarian tribes first came into contact with Islam during their migration through the Eastern European Steppe, including passing through the Khazar Empire, in the 8th century. When the tribes settled in the Carpathian Basin at the end of the 9th century, there were some Muslims among them. In the Hungarian Kingdom, ruled by the House of Árpád up to the 14th century, Muslims held important offices in the financial administration, the military, and the royal guard, and lived on royal estates. 500 years of peaceful coexistence passed. At the end of the Árpád dynasty, Muslims disappeared from historical records, and historians assume that they converted and assimilated into the Hungarian population by the 14th century (Pap \& Glied, 2018).

The present Hungarian Muslim community is young and concentrated in Budapest, with no apparent segregation within the city. The number of Hungarian converts is significant: estimated to be more than 30,000, they make up 10 percent of Hungary's Muslim community, itself less than 1 percent of the total population. Established Hungarian Muslims typically work in the retail and hospitality sector, as architects and engineers, and in healthcare. Their standard of living is not high, and there is a sense of marginalization. In spring 2015, when the Fidesz government 


\section{9}

In many ways Jobbik is similar to other far-right groups in Europe; however, it is alone among radical parties in Europe in pursuing a Muslim-friendly policy. Jobbik's views on Islam differ significantly from those of most parties in Europe that are recognized as nationalist, which consider Muslim people as a serious threat to the safety and the identity of Europe.

launched its anti-refugee and anti-migrant campaign, their relationship with the majority worsened (Pap \& Glied, 2018).

Prior to 2015, the Hungarian Islamic Community (Magyar Iszlám Közösség, MIK) maintained close relations with Jobbik, finding common ground in its anti-Israel stance and foreign policy issues concerning the Gaza strip. They opposed "in principle" Hungarian military participation in the NATO missions to Iraq and Afghanistan (Pap \& Glied, 2018). The current government's "Opening to the East" (Keleti nyitás), a policy of seeking to build relationships with countries all over Asia, is also supported by all Muslim organizations in Hungary (Csicsmann, 2011).

Until the migrant crisis of summer 2015, immigration and integration challenges were not considered problems by the majority of Hungarians. Moreover, Jobbik's positive attitude towards Islam and Muslims living in Hungary was largely accepted by its supporters. Muslims have lived among Hungarians for a thousand years, and in several instances, have taken up arms for the country, most recently in Western Hungary in 1921; the Croatian War of Independence from 1991 to 1995; and Laslovo in 1991. The close relationship of Hungarian Muslim organizations and certain far-right radical groups, including Jobbik, during the 2000 s can be understood in this context. This link has been further strengthened by a common anti-Israel sentiment and support for the establishment of a Palestinian state. In 2012 and 2014, they organized protests against Israeli military actions in Gaza. Vona and other leading Jobbik figures have publicly called Israel an aggressive, racist, and terrorist state that operates "the world's largest concentration camp" in the Gaza Strip. This stand contrasts significantly with that of right-wing parties in Western Europe, in countries with significant Muslim minorities (Pap \& Glied, 2018).

In 2010, Vona explained his attitude toward Islam in Barikád magazine and stated that traditional Islam is a ray of hope (reménysugár) in the fight against Western globalization and neoliberalism. Vona supports the establishment of an independent Palestinian state and promotes the relationship between Turkic peoples and Hungarians. Vona claims that conservative traditions can save globalized consumer societies that are destined to fail, and Christianity has been unable to stop the growth of consumerist societies. On the other hand, Vona and his party argue that the strength of Islamic societies lies in their adherence to conservative values, providing the answer: a halt to globalization (Pap \& Glied, 2018). In a 2013 interview, he also stated: "the actual division in the world may not be between religions, countries and cultures, but between communities still trying to preserve traditions and anti-traditionalist, global liberalism. If you take a closer look, it is the Islamic world that can best resist the unipolar world order led by the US," (Sarkadi-Illyés 2015). Vona's positive attitude to Islam also defined the foreign policy of Jobbik for years (Pap \& Glied, 2018).

One can also follow the traces of this stance vis-à-vis Muslims in a statement of a Jobbik deputy. After Anders Breivik's terror attack in Norway, Jobbik's MP Márton Gyöngyösi published a statement on the party's website, criticizing Breivik's ideology. The title of the statements was: A Hungarian party advocating "Eastern Turn" and return to Asian roots cannot be allied with Western anti-Islamic radicals! 
(Gyöngyösi, 2011). Gyöngyösi stated that Jobbik was criticized by the international press in connection with the attacks, but that his party represents a "unique position" when it comes to their foreign policy strategy: "...These lies were based on the single fact that Breivik mentioned in his 1,500-page diary radical movements in Hungary that he knew of... Jobbik. The media was silent about the fact that Breivik in reality heavily criticized Jobbik for not being anti-Islamic" (Gyöngyösi, 2011). Gyöngyösi suggested that Jobbik is not "anti-Islamic" or "xenophobic," as opposed to many movements in Western Europe. He tried to argue that Hungarians are the only European nation with Asiatic roots and that therefore brotherly relations with such countries as Turkey or Azerbaijan are very important (Gyöngyösi, 2011).

Vona also visited Turkey and declared that it is necessary to cooperate with Muslims. Encouraging Christians, Muslims, and believers of other religions to join in a fight against global liberalism, Vona stated that the countries Hungary now calls "allies" are in fact destroying Hungary's economy by exploiting Hungarians as cheap labor, forcing them to fight in pointless wars, and disrespecting Hungarians' national traditions. Vona encouraged dialogue between cultures and religions (Kowalczyk, 2017).

Although antisemitism and the "Eastern" relationship are widely supported within Jobbik, its members have become divided on close ties with Islam and Muslim states. The question of how a nationalistic-Christian commitment is compatible with a pro-Muslim stance is frequently raised, particularly since the start of the 2015 migrant crisis. Jobbik has also worked hard to reverse its pro-Muslim stance in response to the anti-migrant campaign launched by Fidesz. As the migrant crisis erupted, Jobbik started to describe this crisis in terms of a clash of Muslim and Christian civilizations. Polls also suggested that Jobbik supporters share a radical anti-migrant viewpoint. In February 2016, Fidesz openly called Jobbik's political and ideological shift, from pro- to anti-Muslim, an "identity crisis" (Pap \& Glied, 2018).

In August 2015, parallel to these develop- ments, Imam Miklós Ahmed Kovács, the MIK vice-chairman, declared four radical right-wing organizations, including Jobbik, to be prohibited (haram): "It is religiously haram for all Muslims to support or to vote for or participate in the activities of these groups, parties, or organizations, or to assist them in any way, because that would be an act against Muslims." Kovács justified the prohibition on the grounds that these organizations did not stand up for Muslims and had organized an anti-refugee campaign during the influx of refugees into Hungary. Most interestingly, in his speech, he touched upon the former cooperation between Muslims and these organizations: "Before, many people from these circles became Muslims or supported these parties as Muslims ... many Muslims voted for Jobbik in 2010 and some of them joined the self-defense organizations or the party itself." Since its shift from pro-Muslim to anti-migrant, none of Jobbik's leaders or representatives have visited a Muslim country (Pap \& Glied, 2018). 


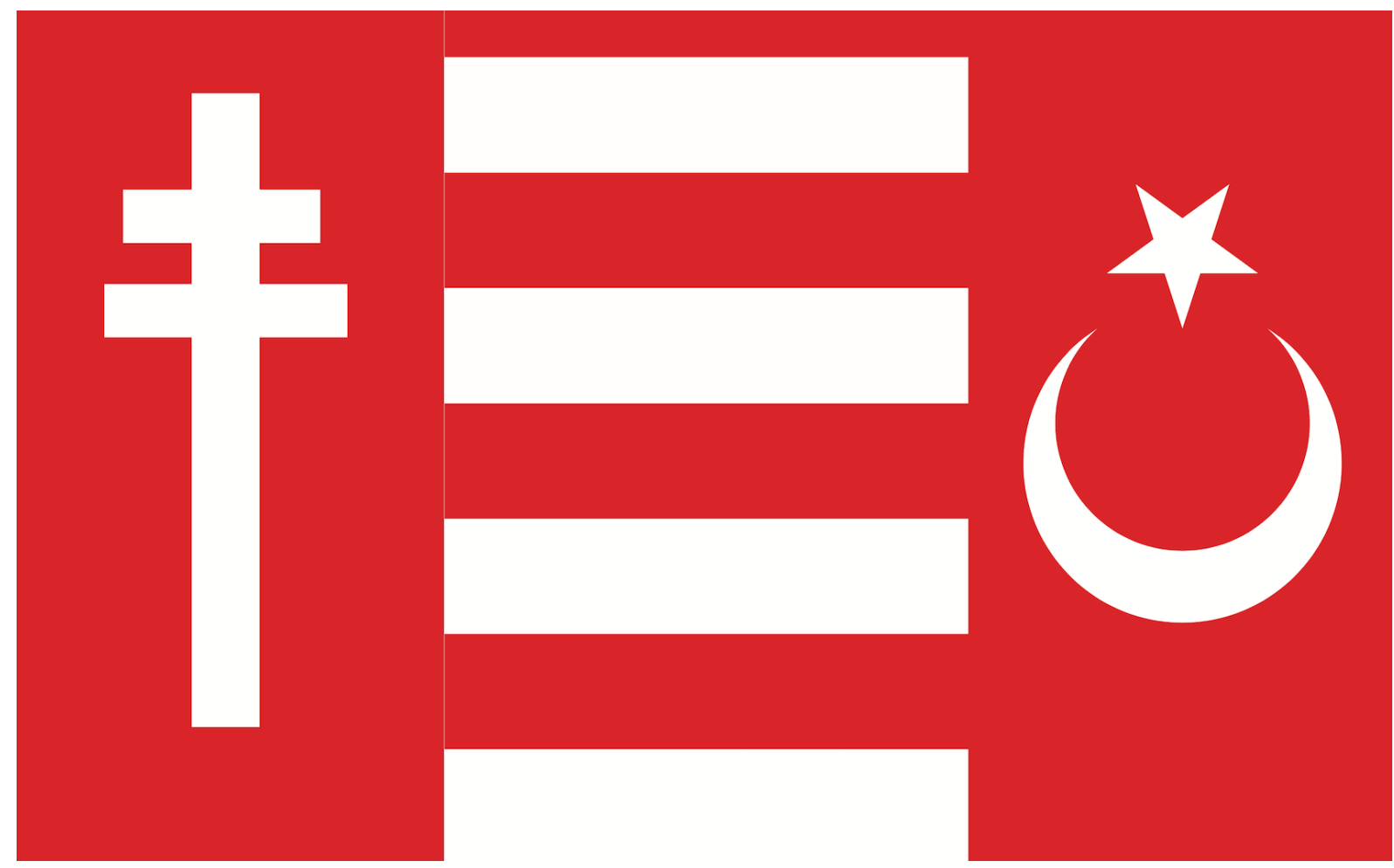

\section{Tracing the Footsteps of Imagined Ances- tors: Turanism}

In practical politics the vital thing is not what men really are, but what they think they are. Accordingly, the Magyars instinctively turned to seek out their long-lost kindred, and the researches of Hungarian scholars, particularly those of the great orientalist Arminius Vambery, disclosed the unexpected vastness of the Turanian world (Stoddard, 1917). According to Kim, Jobbik has attempted to revive the glorious legacy of mythical Turanism, which has contributed significantly to the party's rise (Kim, 2016).

The term "Turanism" is derived from Turan, a word most likely of Persian origin, once used to describe the lands of Central Asia inhabited by nomadic tribes. In seeking to determine when the term first emerged, scholars refer to the two oldest sources known today: the Avesta, the holy book of Zoroastrians; and the Shahnameh, by Ebu-I Kasim-i Ferdowsi (940-1020), which narrates the mythical history of the Persian Empire (Levent, 2016).
The origins of ethnic Hungarians are still being debated, thanks to the emergence of an "alternative history" espoused by right-wing and nationalistic groups, such as Jobbik voters. Evidence suggests that the Magyar tribes migrated from the Ural mountain region in Central Asia, settling in the lowlands of the Carpathian Basin. However, the right-wing alternative historians argue that the Magyars were an ancient warrior people - descendants of Attila the Hun - who lived in the Carpathian Basin for hundreds of years and then migrated all over Europe and Central Asia, finally returning to the Carpathian Basin years later. Although there is no evidence to support this claim, the alternative narrative is regarded as fact by some Hungarians and is touted by present-day far-right parties, romanticizing Turkic-Hungarian connections and contributing to a national pride that is sympathetic to Muslims (Pap \& Glied, 2018).

Proponents of the Hungarian alternative history assert that Hungarian history has been deliberately and systematically falsified by the Habsburgs, the communists, and foreign powers intending to "colonize" Hungary. These theorists claim that foreign academics forged evidence that the Magyars are connected to Finno-Ugric 
people in order to rob Hungarians of their true history as an ancient warrior people, since Finno-Ugric people were considered lower class nomadic peoples. Alternative theorists believe many unproven narratives that supposedly link Hungarians to Asian peoples and a stolen, glorious history. For example, some controversially claim that Hungarians had a historic role in human civilization as descendants of Attila the Hun and that the Hungarian language is related to ancient Sumerian, "proving" that Hungarians are an ancient people (Pap \& Glied, 2018).

Many Hungarian researchers and explorers travelled to Central Asia, seeking to find peoples related to Hungarians. The first to employ the term Turan in Hungarian literature was Ferenc Pulszky, who used it in 1839 as a geographic concept. However, in 1895 Géza Nagy wrote that "Turanian" is synonymous with "Ural-Altaic" and that Turanians should be considered Central Asian nomads: Huns, Cumans, Hungarians, Tatars, Turks, Kyrgyz, etc. In this case, the term is used in an anthropologic meaning (Kowalczyk, 2017). As a geographical and ethno-cultural concept, Turanism is a belief that "aspires to the unification of Uralo-Altaic races, including the Turks of Turkey, the Turkic peoples of Central Asia, Tatars, Hungarians, the aboriginal tribes of Siberia, and even the distant Mongols, Manchus, Koreans, and Japanese" (Akcali \& Korkut, 2012).

The Hungarian people are believed to have originated from East Asia, and the Grand Prince Arpad was assumed to be the direct descendant of Attila (Engel, 2005). This lineage was recorded in the Hungarian chronicle - Gesta Hungarorum (the Deed of Hungarians) - and in the Greek inscription on the Holy Crown which "translates as Geo-vitzas the Faithful King of the Lands of the Turks" (Akcali and Korkut, 2012). This historical narrative offered the Hungarians a sense of Asiatic belonging, which evolved to shape their distinctive identity with its "glorious Scythian-Hunnic past." From the mid-18th century and on, this historical narrative had begun to carry political connotations which essentially served as a counter-ideology to the Western portrayal of Hungarian historiography. In particular, the re-fashioning of the existing historical narrative was seen as significant at countering the influence of German scholarship (Akcali and Korkut, 2012).

In 1910, a group of prominent scientists, nobles, and politicians established the Turanian Society (Kessler, 1967). In 1925, a concise definition of Turanism appeared in Révai nagy lexikon: "It is the Turanian movement, peoples, and states, and the co-operation in the fields of culture, economy, and politics, as well progress in the matters of creative output and development."

It is also important to mention the critical perception of Turanism. Gyula Germanus was its fierce critic. In his opinion, the goal of Turanism was not to provide reliable knowledge, but to foster "an imaginary, fictitious idea of kinship" in order to reap political benefits. (Kowalczyk, 2017).

In an attempt to preserve Turanism, Hungarian aristocrats consciously encouraged the entrenchment of the Uralo-Altaic narrative into Hungarian intellectual discourse. Yet this attempt was hampered by the dominance of regional hegemonic foreign power, and it was the Ottomans, the Habsburgs, and the Russians who were primarily held accountable for Turanism failing to take hold. Thus, it was only after the end of the WWI that saw ripe conditions for the revival of Turanism. The idea was especially appealing to those who saw the post-war truncation of Hungary as unjust and inadmissible and pined for the days of Greater Hungary. Still, this resuscitated idea failed to take hold - a failure which was due to Hungary's defeat in WWII and the imposition of Communist rule thereafter (Kim, 2016).

The fall of the Iron Curtain allowed for a re-emergence of the Turanist movement. The largest and the most important group appears to be the Hungarian-Turan Fund under the leadership of András Zsolt Bíró. The modern Turanist movement has different opportunities than those available to its predecessors. First of all, the internet is a very useful tool in promoting Turanism. Thanks to the internet, one can obtain knowledge about Turanists and their vision of history, but it is also possible to buy Turanist clothes, caps, pendants, mugs, arches and knives of ancient 
For Jobbik, Turanism, with its emphasis on the unification of Uralo-Altaic brethren, seems to be an ideal means of achieving this goal. Turanism, it was thought, might serve as counter-ideology to offset the influence of the Atlanticists. Furthermore, Jobbik might have seen Hungary's turn to the East as an opportunity to expand into new markets.

warriors, as well as many other gadgets. Turanist themes are also present in songs of bands representing the Hungarian "National Rock" genre. For example, the famous Hungarian band Kárpátia has written a song titled Turul, about the bird from Hungarian mythology. Kárpátia also recorded a song dedicated to Cumans, the nomadic Turkic people who settled in Hungary in the Middle Ages. Turanism became a part of Hungarian mass culture, although mostly among nationalists (Kowalczyk, 2017).

The transition to democracy naturally created an opportunity for the "spiritual revival" of Turanism. These attempts did not, however, draw a great deal of support from the wider community. The rejuvenation of Turanism began to gather momentum only after Jobbik included it on its own political agenda. Jobbik openly adheres itself to Pan-Turanism (Ghosh, 2013). It is noteworthy to point out that modern Hungarian Turanism, particularly as it is represented by Jobbik, displays strong anti-Western attitudes. At the time when Turanism reemerged onto the Hungarian political scene, Europe was grappling with financial crises, and in Jobbik's eyes, the misleading role of the Euro-Atlantic community was primarily to blame for the country's socio-economic ills. Thus, Jobbik questioned the wisdom of Hungary's membership in the Euro-Atlantic community. Vona argued that Hungary's alliance with the EU is counter-productive to promoting its national interests (Vona, 2012).

In view of this, Jobbik's anti-EU and anti-liberalism stances are hardly a surprise. Jobbik sought to develop and promote an alternative geopolitical discourse that might more closely align with Hungary's national interests and might challenge the dominance of Euro-Atlanticism (Kim, 2016). For Jobbik, Turanism, with its emphasis on the unification of Uralo-Altaic brethren, seems to be an ideal means of achieving this goal. Turanism, it was thought, might serve as counter-ideology to offset the influence of the Atlanticists (Akcali and Korkut, 2015). Furthermore, Jobbik might have seen Hungary's turn to the East as an opportunity to expand into new markets. This pragmatic consideration may explain certain Jobbik members' support for Turanist ideas. Moreover, Hungary is in a unique position within Europe, one that allows it to facilitate engagement with Eurasian culture (Kim, 2016). This dual identity, drawing on both European norms and Asian values, was embedded in the historical consciousness of Jobbik members.

Turanism is a very important part of Jobbik's program. Jobbik regularly organized a series of socio-cultural programs, including Kurultaj, which was most well-known among pro-Turanists (Dettke, 2014). In some Altaic languages the word Kurultaj means "meeting of the tribes," something which occurs among many nomadic peoples. Such meetings are also very important for Hungarian culture and mentioned throughout Hungarian literature. The Nagy Kurultaj (Great Kurultaj) is held every summer, in the village of Bugac, $160 \mathrm{~km}$ south of Budapest and close to Kiskunság National Park. Before every Kurultaj, organizers construct a large nomadic village with innumerable Turanian tents (yurts); there are also special corrals and stables (Kowalczyk, 2017). In the summer of 2010, a quarter million people gathered at Bugac. Such attendance shows the growing popularity of Turanism. In 2012, a decision was made that the event will be held once every two years and that repre- 
sentatives of all Turanian nations will be invited (Kowalczyk, 2017). It can be argued that Jobbik's rise is predominantly due to the party's strategy in which they've re-shaped Hungarian national identity, forming an ideological narrative based in mythic Turanism (Kim, 2016).

An analysis of Jobbik's vision of Hungarian foreign policy also shows the influence of Turanism. Whenever Jobbik's politicians speak out about Hungarian origins and affiliation, they readily support the theory that Hungarians are one of the Turanian peoples (Kowalczyk, 2017).

Jobbik politicians not only speak about Turanism, but they also travel to countries considered Turanian. In October 2013, Vona paid a visit to Turkey, where he met with university students and delivered lectures. He was talking about Hungarian-Turkish kinship, common ancestors, and a need for cooperation. He suggested that the mission of Turanism could be to build bridges between the West and the East, between Islam and Christianity. The party remains consistent in supporting states and nations recognized as Turanian while also trying to build relationships with them. Jobbik supports Azerbaijan in its conflict against Armenia over $\mathrm{Na}$ gorno-Karabakh. In February 2013, an article titled Jobbik expresses solidarity with brotherly Azeri nation was released on Jobbik's website (jobbik.com, 2013). It is surprising to many that Jobbik, often considered to be "far-right" or "xenophobic," promotes Turanism and calls for reconciliation between Christians and Muslims (Kowalczyk, 2017).

Lastly, Jobbik tries to utilize Turanistic images and symbols for its benefit. In its manifesto, Jobbik promised to constitutionally protect ancient national symbols that have been oft-attacked: The Holy Crown, Hungary's historic flags, and the Turul-bird emblem (Guide, 2010). 


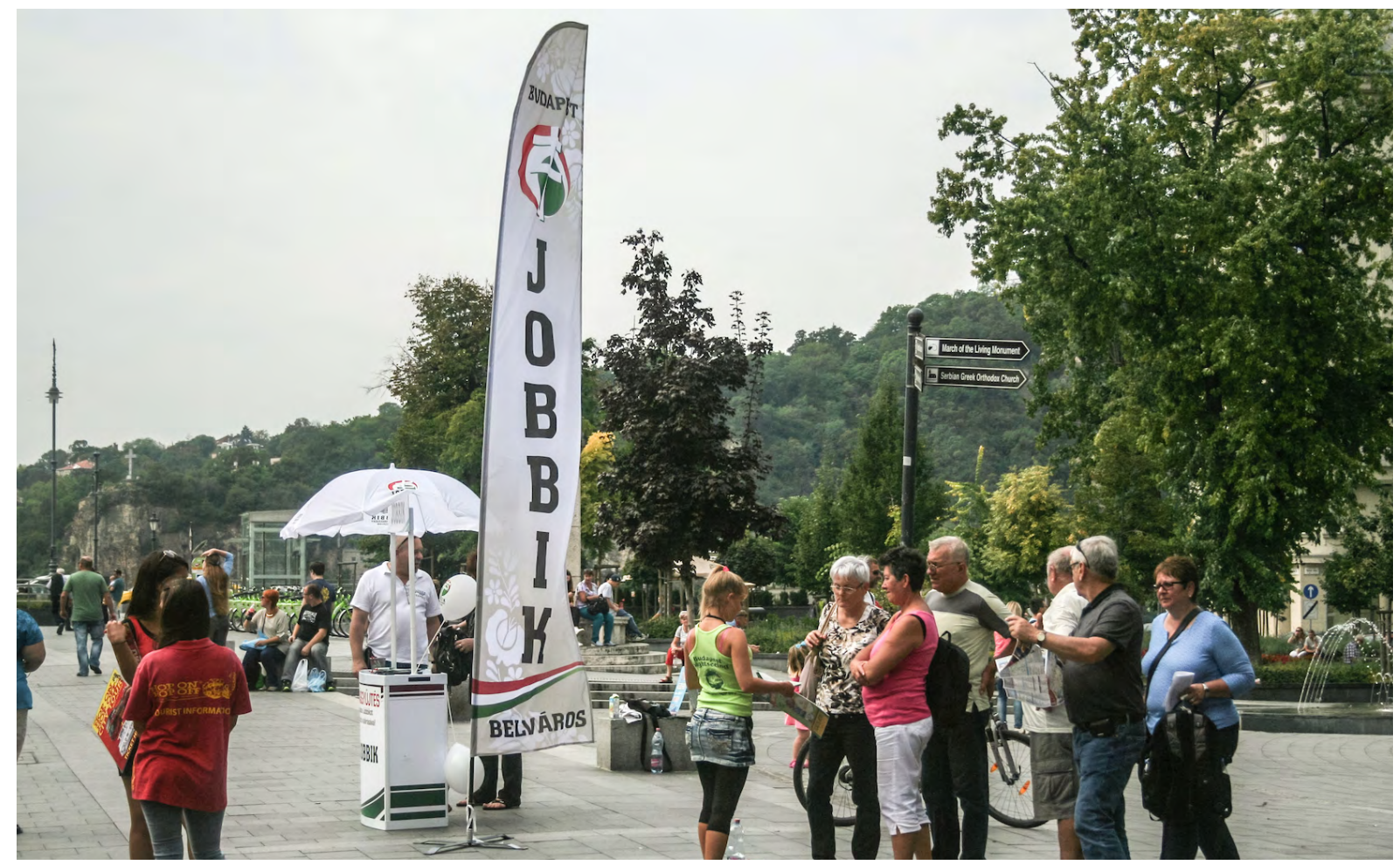

Jobbik banner and poster in the streets of Budapest for electoral propaganda on September 6, 2014.t

\section{"Eastern Turn” \& Ties with Russia, Iran, and Turkey}

In Jobbik's ideology, very diffuse elements complement each other. In addition to incorporating Hungarian history from the time of paganism, as well as nationalistic and Christian ideas, there is also a spiritual and esoteric dimension. Together with the anti-EU arguments and a pro-Russia orientation, an anti-immigrant stance exists simultaneously with a pro-Muslim stance. This stance primarily focuses on Iran and Turkey (Pap \& Glied, 2018). Since its formation, Jobbik has been very critical of the international policy of the EU and the US and considers Hungary to be a victim of the West. What is more, Jobbik strongly criticizes globalism, liberalism, and anti-traditionalism, which it considers to be features of modern Western societies. Because of this, Jobbik's "Eastern Turn" appears to be a turn away from the West (Kowalczyk, 2017).

In a sense, Jobbik could be considered a revisionist party, one which disagrees with the provisions of the Treaty of Trianon
(1920), according to which Hungary lost a vast majority of territories. The Treaty of Trianon is one of the reasons Jobbik is so mistrustful of the West. Jobbik also condemns the Euro-Atlantic co-operation, perceiving it as a vehicle for the US to secure its interests. Therefore, the party calls for the replacement of Euro-Atlantic co-operation with Euro-Asiatic co-operation. Putting aside historical animosity towards Moscow, Jobbik considers Russia a desirable ally for Hungary (Kowalczyk, 2017). The party regarded the accession of Hungary a failure and looked at the EU as an organization that did not serve the interests of Hungarians (Jobbik.com, 2010). However, following Brexit and the continuous debates on the future of the EU, Jobbik has reassessed its views on the $E U$ and started to emphasize that an EU reform could make the Union advantageous for European nations (Kroet, 2016).

Jobbik's foreign policy - its "Eastern Turn" or "Opening to the East" (Keleti nyitás) - is aimed at reducing dependence on Western resources. In Hungary, the "East" is considered a region which is made up of all the countries in the Middle East and Asia - all non-European countries east of Hungary. In several speeches on behalf of Jobbik, former party leader 
Vona advocated forming alliances with "Eastern" powers. Jobbik rhetoric regularly refers to uprisings from Hungarian history to symbolize its commitment to defending Hungary against Western powers (Pap \& Glied, 2018). In April 2011, Vona presented the Béla IV Plan, in which the economic potential of Russia, China, Turkey, Central Asia, the Arab countries, and Iran are put forward as a means of ending Hungary's international financial dependence on the EU and Western multinational corporations, which he sees as injurious to Hungary's sovereignty (Pap \& Glied, 2018).

Jobbik also stated in its party manifesto that they will develop a partnership with Russia and will pursue cooperation with the Far East and Southeast Asian region. With the US they intend to develop a kind of bilateral relationship, which consistently promotes national interests. They shall also widen diplomatic relations with Arab nations and will promote the creation of an independent Palestinian state. In the case of Central Asian nations, Jobbik intends to reinforce the development of political and economic ties on the basis of cultural relationships, given their ancient kinship with the peoples of that region (Guide, 2010).

Jobbi believes the growing countries of the East (China, India, Russia, Turkey, Kazakhstan, Indonesia) have unexplored potential for trade and economic development. Jobbik promised to turn foreign trade relations eastward to guarantee these economies the opportunity of a "bridgehead" towards the markets of the EU. Jobbik also promised to reappraise the necessity of the country's involvement in current NATO operations (Guide, 2010). According to A. Buzogány, Jobbik's anti-NATO and anti-EU policies are influenced by Russia. Press reports also showed that the Kremlin has been involved in funding extreme right-wing forces in the EU, including Jobbik, which underwent an unexpectedly sharp pro-Russian turn during the 2010s (Buzogány, 2017). Politically, the most troubling development for the EU are persistent suggestions of financial connections between Jobbik and Russia and Iran (Murer, 2015).

Not long after Jobbik's successful show-

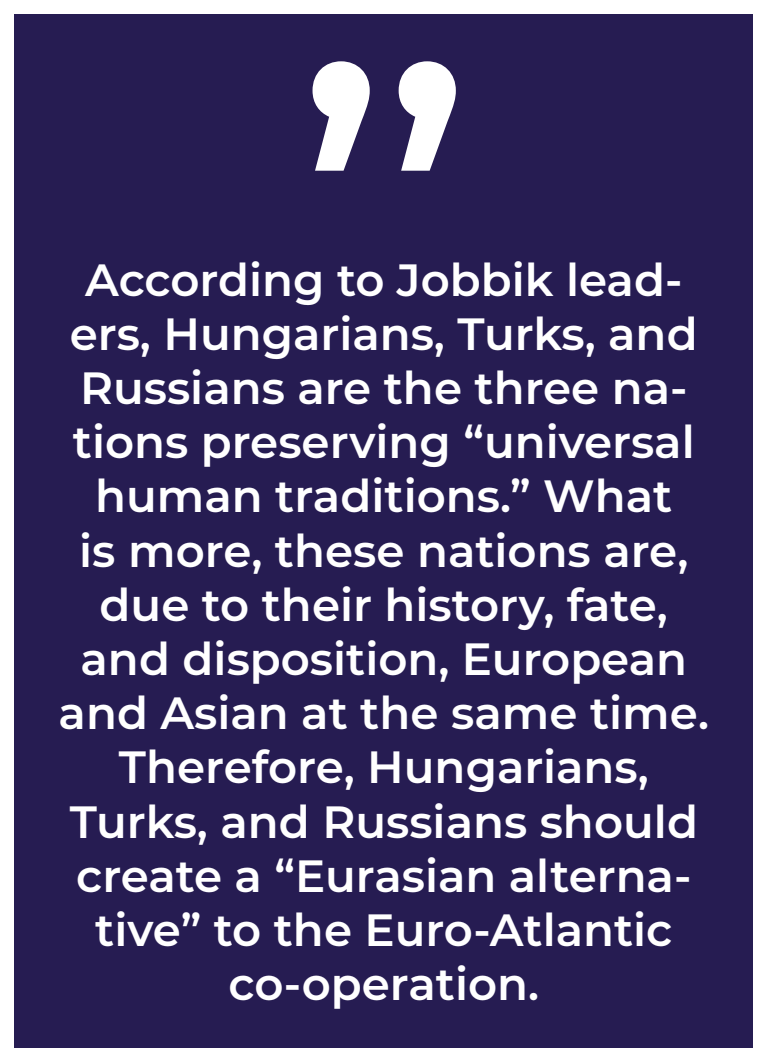

ing in the 2010 parliamentary elections, Gabriel Ronay, writing in the Scottish broadsheet The Herald, reported that the Hungarian Public Prosecutor's Office was investigating claims that Béla Kovács, then a Jobbik foreign policy advisor, was Moscow's money channel, bringing funds directly from the Kremlin into the party's coffers (Ronay, 2010). In May 2014, the assertions of a connection between Jobbik and Moscow continued when Jávor Benedek of the Hungarian political party "Politics Can Be Different" (LMP), claimed in the Budapest daily Magyar Nemzet that Béla Kovács, now a Jobbik MEP, is regarded in Brussels as "a lobbyist for Russia and Gazprom, someone whose career clearly demonstrates a commitment to Russia." It was further alleged that Kovács was spying on EU institutions for the Russians (XpatLoop, 2014).

The consequences of this connection are significant, as Jobbik MEPs oppose EU sanctions against Russia, inflame the Ukrainian crisis, and disrupt EU foreign policy. This confluence of Russian interests and cooperation from Jobbik is most apparent in the rhetoric of "Eurasianism." Jobbik suggests that just as Crimea is Russian, the Carpathian region of western Ukraine is Hungarian. Furthermore, Vona 
said in a June 2015 speech that "Europe is in crisis; Europe is sick" (Murer, 2015). Whether Jobbik is actively anti-EU or pro-Russian, the activities in the European Parliament and the close connections revealed in frequent trips and lectures, such as Vona giving a lecture at Lomonosov University in Moscow in May 2013 at the invitation of Alexandr Dugin, irritate Brussels; such stances and actions have led to some political scientists wondering whether Jobbik is acting as "Russia's Trojan Horse." (Petsinis, 2014).

Jobbik's politicians express respect for Dugin's geopolitical ideas. Dugin is the main ideologist of Eurasianism; he and Vona have even discussed common goals. According to Vona, Hungarians, Turks, and Russians are the three nations preserving "universal human traditions." What is more, these nations are, due to their history, fate, and disposition, European and Asian at the same time. Therefore, Hungarians, Turks, and Russians should create a "Eurasian alternative" to the Euro-Atlantic co-operation (Kowalczyk, 2017). According to Murer, it is ironic that, via the platform of the EU, and especially the European Parliament, Jobbik is able to find a far larger audience to disseminate its anti-capitalist, antisemitic, and anti-Roma views. Jobbik also disrupts EU attempts to speak with one voice on issues ranging from human rights to the crisis in Ukraine, while at the same time appearing to promote Russian interests (Murer, 2015). 


\section{CONCLUSION}

Although Jobbik identifies itself as a "principled, conservative and radically patriotic Christian party" whose "fundamental purpose" is the protection of "Hungarian values and interests," it could not hide its racist, populist, and far-right character. It is accepted widely that Jobbik's ideology is neo-Fascist and neo-Nazist and that combines militant ethno-nationalism with antisemitism and anti-Roma racism.

As a revisionist political party in its foreign policy, Jobbik also advocates a militant revanchism and seeks the "reunification" of the Hungarian nation and a revision of the 1920 Treaty of Trianon which determined the borders of present-day Hungary, granting the new country only 36 percent of the kingdom's pre-war population. Jobbik's Greater Hungarian irredentist claims are also reflected in pleas for cross-border ethnic self-determination. For instance, Jobbik demands "territorial autonomy" for parts of Romania with large Hungarian populations and desires to make Trans-carpathian Ukraine an independent Hungarian district. Since a quarter of ethnic Hungarians live outside the country, Jobbik dedicates itself to supporting the cause of significant Hungarian minority populations abroad. Thus, it stirs up ethnic hatred in neighboring countries.

Since Jobbik believes that Hungarian diaspora communities face discrimination in their host countries, the party calls for Hungarian communities in neighboring states to receive territorial autonomy if they form a local majority. Jobbik further argues that all other Hungarian diaspora communities should receive "cultural autonomy." Despite its extensive efforts at "image refurbishment" in recent years, Jobbik remains a populist, revisionist, racist, radical right-wing party that threatens to destabilize Hungary, the neighboring region, and the $\mathrm{EU}$ - especially if it could secure a ruling majority in upcoming elections 


\section{REFERENCES}

- (2003). "For the people - Manifesto on Jobbik's fundamental principles for government," jobbik.com, https://www.jobbik.com/manifesto_on_the_guidelines_for_a_future_jobbik_ led_government (accessed on May 22, 2020).

- (2009). "Jobbik confident of winning EP seat, party leader says," politics.hu. May 13, 2009, https://web.archive.org/web/20110810093412/ http://www.politics.hu/20090513/jobbik-confident-of-winning-ep-seat-party-leader-says/(accessed on May 22, 2020).

- (2009). "Police investigate 'new' Magyar Gárda; former minister mulls banning Jobbik". Politics.hu. July 14, 2009. https://web.archive.org/web/20141204135254/ http://www.politics. hu/20090714/police-investigate-new-magyar-garda-former-minister-mulls-banning-jobbik/ (accessed on May 22, 2020).

- (2010). A Guide to Jobbik's Parliamentary Electoral Manifesto for National Self-determination and Social Justice,Jobbik Foreign Affairs Committee, https://www.jobbik.com/sites/ default/files/Jobbik-RADICALCHANGE2010.pdf(accessed on May 21, 2020).

- (2010). "Radical change - Jobbik's electoral manifesto 2010." Jobbik.com https://www.jobbik.com/sites/default/files/Jobbik-RADICALCHANGE2010.pdf (accessed on May 28, 2020).

- (2011). "Hungary Roma battle far-right vigilantes," BBC News, 27 April 2011. https://www. bbc.com/news/world-europe-13206261 (accessed on May 22, 2020).

- (2011). "Right-wing Militants on Patrol: A New Wave of Anti-Roma Violence in Hungary," Der Spiegel, 27 April 11, https://www.spiegel.de/international/europe/right-wing-militantson-patrol-a-new-wave-of-anti-roma-violence-in-hungary-a-759349.html (accessed on May 22, 2020).

- (2012). "Hungarian MP denounced for 'Jewish list' call." Al Jazeera, Nov. 28, 2012. https:// www.aljazeera.com/news/europe/2012/11/2012112722413396434.html (accessed on May 27, 2020).

- (2012). "Discovering Jewish roots - former anti-Semitic party leader meets with rabbi Köves," Free Hungary, August 8, 2012. https://archive.vn/20130217205554/ http://freehungary.hu/archives-new/1259-discovering-jewish-roots-former-anti-semitic-party-leader-meets-with-rabbi-koeves.html\#selection-363.1-363.83 (accessed on May 27, 2020).

- (2012). "Hungary: Far-right leader demands lists of Jews." Ynetnews.com. 27 November 2012. https://www.ynetnews.com/articles/0,7340,L-4312434,00.html (accessed on May 27, 2020).

- (2013). "Jobbik rally against World Jewish Congress in Budapest." BBC News, May 4, 2013. https://www.bbc.com/news/world-europe-22413301 (accessed May 27, 2020).

- (2013). "Outrageous police reaction to crimes against Hungarian Roma," Hungarian Spectrum, October 7, 2103. https://hungarianspectrum.org/2013/10/07/outrageous-police-reaction-to-crimes-against-the-hungarian-roma/ (accessed on May 22, 2020).

- (2013). "Jobbik Expresses Solidarity with Brotherly Azeri Nation." Jobbik.com, http://jobbik.com/jobbik_expresses_solidarity_brotherly_azeri_nation (accessed on May 28, 2020).

- (2014). "Roma in Europe: Demanding justice and protection in the face of violence". Amnesty International, April 8, 2014, https://www.amnesty.org/en/latest/news/2014/04/roma-europe-demanding-justice-and-protection-face-violence/(accessed on May 22, 2020). 
- (2014). "Jewish leader condemns Jobbik politician's Holocaust remarks." politics.hu. Feb.

13, 2014. https://web.archive.org/web/20140222043212/ http:/www.politics.hu/20140213/jewish-leader-condemns-jobbik-politicians-holocaust-remarks/ (accessed on May 27, 2020).

- (2014). "Investigation under way against Jobbik MEP for spying against EU," XpatLoop, May 16, 2014. https://xpatloop.com/channels/2014/05/investigation-under-way-against-hungarian-jobbik-mep-for-spying-against-eu.html (accessed on May 28, 2020).

- (2015). "Hungary wants EU death penalty debate." BBC News, April 30, 2015. https://www. bbc.com/news/world-europe-32523384 (accessed on May 28, 2020).

- (2015) "Jobbik initiates parliamentary day of debate on capital punishment." Daily News Hungary. May 2, 2015.https://dailynewshungary.com/jobbik-initiates-parliamentary-day-of-debate-on-capital-punishment/ (accessed on May 28, 2020)

- (2015). "Rally in Ex-Synagogue Sparks Fury in Hungary," Aljazeera, 15 February 2014, https://www.aljazeera.com/news/europe/2014/02/rally-ex-synagogue-spurs-anger-hungary-201421525319103646.html(accessed on May 22, 2020).

— (2015). "Gábor Vona on the wildling." jobbik.com. April 24, 2015.https://www.jobbik.com/ gabor_vona_on_the_wildling (accessed on May 28, 2020).

- (2017). "What does Catalonia's story tell us, Hungarians?" Daily News Hungary. 24 October 2017. https://dailynewshungary.com/catalonias-story-tell-us-hungarians/ (accessed on May 28, 2020).

- (2017). "Hungary's Jobbik ditches far-right past to challenge Orban in 2018," Reuters. Jan 11, 2017. https://www.reuters.com/article/us-hungary-jobbik/hungarys-jobbik-ditches-farright-past-to-challenge-orban-in-2018-idUSKBN14V1PW (accessed on May 22, 2020).

- (2017). "Jobbik leader ready to apologize to Jews and Roma." Budapost, August 17, 2017, https://www.budapost.eu/2017/08/jobbik-leader-ready-to-apologize-to-jews-and-roma/ (accessed on May 28, 2020).

- (2018). "What to watch at Hungary's elections." Reuters, April 5, 2018. https://www.reuters.com/article/us-hungary-election-explainer/what-to-watch-at-hungarys-electionsidUSKCN1HC1BU (accessed on May 28, 2020).

Ádám, Magyar. (2020). "Kettészakadt a közvélemény Magyarország szövetségeseivel kapcsolatban". Euronews (in Hungarian), February 27, 2020, https://hu.euronews. com/2020/02/27/ketteszakadt-a-kozvelemeny-magyarorszag-szovetsegeseivel-kapcsolatban (accessed on May 22, 2020).

Aisch, G., Pearce, P., Rousseau, B. (2016). "How Far Is Europe Swinging to the Right." The New York Times, Oct. 23, 2017. http://www.nytimes.com/interactive/2016/05/22/world/europe/europe-right-wing-austria-hungary.html?_r=0(accessed on May 28, 2020).

Akçalı, E., \& Korkut, U. (2012). "Geographical Metanarratives in East-Central Europe: Neo-Turanism in Hungary." Eurasian Geography and Economics, 53(5), 596-614.

Almássy, Ferenc. (2016). “The Jobbik at 53\% among 15-34." Visegrád Post. April 6, 2016. https://visegradpost.com/en/2016/04/06/the-jobbik-at-53-among-15-34/ (accessed on May 28, 2020).

Bayer, Lili. (2017). “Exclusive: In First Talk with Jewish Media, Hungary's Far Right Leader Strikes A New Pose." The Forward, Feb. 8, 2017. https://forward.com/news/world/362663/exclusive-in-first-talk-with-jewish-media-hungarys-far-right-leader-strikes/ (accessed on May 27, 2020). 
Bernath, Anikó; Juhász, Attila; Krekó, Péter and Molnár, Csaba. (2013). "The Roots of Radicalism and Anti-Roma Attitudes on the Far-Right," Tarki.hu, http://citeseerx.ist.psu.edu/viewdoc/download?doi=10.1.1.423.2311\&rep=repl\&type=pdf (accessed on May 27, 2020).

Bíro-Nagy, A., Boros, T., Varga, A. (2012). "Right Wing Extremism in Hungary." International Policy Analysis. Friedrich Ebert Stiftung Forum, Berlin.

Buzogány, A. (2017). "Illiberal democracy in Hungary: Authoritarian diffusion or domestic causation?" Democratization: Clusters of Authoritarian Diffusion and Cooperation: The Role of Interests vs. Ideology? Guest Editors: André Bank and Kurt Weyland, 24(7), 13071325.

Chomsky, N. (2011). "Is the World Too Big to Fail?" Salon, April 21, 2011, http://www.salon. com/2011/04/27/global_empire_united_states_iraq_noam_chomsky/laccessed on May 28, 2020).

Csaky, Zselyke. (2016). "The Far-Right Hungarian Party Jobbik Is Moderating. Is That a Good Thing?" Freedom House, Oct. 4, 2016. https://freedomhouse.org/article/far-right-hungarian-party-jobbik-moderating-good-thing (accessed on May 28, 2020).

Csicsmann, L. \& Vékony, D. (2011). "Muslims in Hungary: A Bridge between East and West?" in Bures, J. (ed.), Muslims in Visegrad, Prague, Institute of International Relations Prague.

Dunai, Marton. (2017). "Hungary's Jobbik ditches far-right past to challenge Orban in 2018". Reuters, Jan. 11, 2017. https://www.reuters.com/article/us-hungary-jobbik/hungarys-jobbikditches-far-right-past-to-challenge-orban-in-2018-idUSKBN14V1PW (accessed on May 27, 2020).

Engel, P. (2005). "The early middle ages," in: Toth, I. (Ed.), A Concise History of Hungary. Corvina.Osiris, Budapest.

Fabry, A., \& Sandbeck, S. (2019). "Neoliberalism, crisis and authoritarian-ethnicist reaction: The ascendancy of the Orbán regime." Competition \& Change, 23(2), 165-191.

Freeman, Colin. (2009). "Feminine face of Hungary's far-Right Jobbik movement seeks MEP's seat." The Daily Telegraph, May 24, 2009. https://www.telegraph.co.uk/news/worldnews/europe/eu/5372983/Feminine-face-of-Hungarys-far-Right-Jobbik-movement-seeksMEPs-seat.html (accessed on May 27, 2020).

Frucht, R. C. (2005). Eastern Europe v2: An introduction to the people, lands, and culture. Santa Barbara, Calif: ABC-CLIO. p. 359-360.

Ghosh, Palash. (2013). "Strange Bedfellows: Hungarian Far-Right Jobbik Party Embraces Muslim Nations, Seeks 'Eurasian' Ideal of Statehood," International Business Times, June, 12,2013

https://www.ibtimes.com/strange-bedfellows-hungarian-far-right-jobbik-party-embraces-muslim-nations-seeks-eurasian-ideal (accessed on May 27, 2020).

Goettig, Martin \& Christian Lowe. (2014). "Special Report: from Hungary, far-right party spreads ideology, tactics," Reuters, April 9, 2014, https://www.reuters.com/article/uk-europe-farright-special-report/special-report-from-hungary-far-right-party-spreads-ideology-tactics-idUKBREA380IX20140409 (accessed on May 23, 2020).

Gregor, Anikó. (2014). "Hungary." in: Niko Hatakka, Young and Easily Allured? A Comparative Analysis on the Relationship between Populism and Youth in Europe. Brussel: Foundations of European Progressive Studies. April, 3 2014, http://www.feps-europe.eu/assets/ d4c37f73-925c-4358-a524- c143f5d4d301/wg_populism.pdf (accessed on May 28, 2020). 
Gyöngyösi, M. (2011). Statement of Jobbik Against Accusations re Breivik-Case. (2011). https://www.jobbik.com/statement_jobbik_against_accusations_re_breivik-case (accessed on May 27, 2020).

Halasz, K. (2009). "The Rise of the Radical Right in Europe and the Case of Hungary: 'Gypsy crime' defines national identity?" Development, 52, 490-494. https://doi.org/10.1057/ dev.2009.63

Heneghan, Tom. (2013). "Christian churches back Jews facing anti-Semitism in Hungary." Reuters, May 14, 2013. http://blogs.reuters.com/faithworld/2013/05/14/christian-churches-back-jews-facing-anti-semitism-in-hungary/(accessed on May 27, 2020).

Inder Singh, Anita (2000). Democracy, ethnic diversity, and security in post-communist Europe. Praeger. p. 97. ISBN 0-275-97258-5.

Ivanis, J., Dobias, K., et al. (2014). Accelerating Patterns of Anti-Roma Violence in Hungary. A Report from the Francois-Xavier Bagnoud Center for Health and Human Rights. Harvard School of Public Health and Harvard University.

Jordan, Michael J. (2010). "The Roots of Hate." World Policy Journal, 27, no. 3: 99-111.

Karácsony, Gergely, and Daniel Róna. (2011). "The Secret of Jobbik. Reasons Behind the Rise of the Hungarian Radical Right." Journal of East European and Asian Studies, 2 (1): 61-92.

Karl, Philipp. (2017). “Hungary's Radical Right 2.0." Nationalities Papers 45, no. 3: 345-55.

Kessler, J. (1967). Turanism and Pan-Turanism in Hungary: 1890-1945. (Ph.D. thesis). Berkeley: University of California.

Kim, Dae Soon. (2016). "The rise of European right radicalism: The case of Jobbik." Communist and Post-Communist Studies, 49(4), 345-357.

Kroet, Cynthia. (2016). "Hungary's far-right Jobbik says leaving EU no longer on the agenda." Politico, March 6, 2016. https://www.politico.eu/article/hungarys-far-right-jobbik-leadergabor-vonasays-leaving-eu-no-longer-on-the-agenda/(accessed on May 28, 2020).

Kovacs, Andras. (2012). "Antisemitic Prejudice and Political Antisemitism in Present-day Hungary," Journal for the Study of Antisemitism, 4, no. 2 (2012): 443-469.

Kowalczyk, Michał. (2017). "Hungarian Turanism. From the Birth of the Ideology to Modernity - an Outline of the Problem." Historia I Polityka, (20 (27)), 49-63.

Lahav, Yehuda. (2009). "Proud Hungarians must prepare for war against the Jews," Haaretz, June 6, 2009. https://www.haaretz.com/1.5059050 (accessed on May 27, 2020).

LeBor, Adam. (2009). "Jobbik: Meet the BNP's fascist friends in Hungary," The Times, June 9, 2009. https://www.thetimes.co.uk/article/jobbik-meet-the-bnps-fascist-friends-in-hungary-w535fd6whrO (accessed on May 27, 2020).

Levent, S. (2016). "Common Asianist intellectual history in Turkey and Japan: Turanism." Central Asian Survey, 35(1), 121-135.

McLaughlin, Daniel. (2017). "Hungarian political foes unite against government 'attack on nationalists."' The Irish Times, Dec. 15, 2017. https://www.irishtimes.com/news/world/europe/ hungarian-political-foes-unite-against-government-attack-on-nationalists-1.3329144 (accessed on May 28, 2020).

Molnar, Miklos. (2001). A Concise History of Hungary, Cambridge University Press, 2001, p. 
Moore, Matthew. (2008). "Hungarian extremist running far-right website from UK," The Daily Telegraph, Nov. 10, 2008. https://www.telegraph.co.uk/news/uknews/3416496/Hungarian-extremist-running-far-right-website-from-UK.html

Mudde, Cas. (2007). Populist Radical Right Parties in Europe. Cambridge: Cambridge University Press.

Murer, Jeffrey. (2015). "The Rise of Jobbik, Populism, and the Symbolic Politics of Illiberalism in Contemporary Hungary." The Polish Quarterly of International Affairs 24, no. 2: 79-III.

Odehnal, Bernhard. (2011). Right wing extremist groups and religion in Central Europe, Working papers 2011. Brno: Institute for Comparative Political Research.

Pal, G. (2007). "Megalakul a Magyar Garda (The Hungarian Guard was Formed)". Magyar Nemzet. August 25, 2007.

Pap, Norbert \& Glied, Viktor. (2018). "Hungary's Turn to the East: Jobbik and Islam." Europe-Asia Studies, 70, no. 7 (2018): 1036-054.

Paterson, Tony. (2014). Hungary election: Concerns as neo-Nazi Jobbik party wins $20 \%$ of vote". The Independent, April 7, 2014, https://www.independent.co.uk/news/world/europe/ concerns-as-neo-nazi-jobbik-party-wins-20-of-hungary-vote-9244541.html (accessed May 22, 2020).

Petsinis, Vassilis. (2014). "Random friends or asymmetric Trojan horses?" Open Democracy, Dec. 18, 2014, https://www.opendemocracy.net/en/can-europe-make-it/random-friends-orasymmetric-trojan-horses-analysis-of-far-ri/(accessed on May 28, 2020).

Rev, Istvan. (2015). "Hungary's Politics of Hate." The New York Times, Sept. 25, 2015. http:// www.nytimes.com/2015/09/26/opinion/hungarys-politics-of-hate.html (accessed May 28, 2020).

Róna, Dániel. (2020). "Far-right generation? Reasons behind the popularity of Jobbik among the youth", ECPR, https://ecpr.eu/Filestore/PaperProposal/d599a34f-cafd-4bfa87ad-9ae9f1956ba4.pdf (accessed on May 28, 2020).

Ronay, G. (2010). "Hungary's far-right backed by 'rolling Moscow roubles'." Herald Scotland, June 13, 2010.

Saltman, Erin Marie. (2014). "Political Youth Organizations and camps in Hungary." Hungary 2014, Feb. 15, 2014, https://hungary2014.wordpress.com/2014/02/15/political-youth-organizations-and-camps-in-hungary/ (accessed on May 28, 2020).

Sarkadi-Illyés, C. (2015). "Gátlástalan módon provokál az atv," Alfahír, Sept. 1, 2015, https://alfahir.hu/gatlastalan_modon_provokal_az_atv (accessed on May 27, 2020).

Stephens, P. (2017). "Viktor Orban's Hungary crosses to Europe's dark side," Financial Times, July 13, 2017. https://www.ft.com/content/2032f1c2-66e5-11e7-8526-7b38dcaef614 (accessed on May 28, 2020).

Stoddard, T. (1917). "Pan-Turanism." The American Political Science Review, 11(1), 12-23.

Székely, Tamás. (2016). "Hardliner MP Előd Novák Kicked Out of Jobbik's Parliamentary Group." Hungary Today. June 7, 2016. https://hungarytoday.hu/hardliner-mp-elod-novak-kicked-jobbiks-parliamentary-group-11164/ (accessed on May 22, 2020). 
Szigeti, Tom. (2017). "Hungarian Far-Right Jobbik Party Holds Year-Opening Conference," Hungary Today, Jan. 30, 2017. https://hungarytoday.hu/hungarian-far-right-jobbik-party-holds-year-opening-conference-28046/ (accessed on May 28, 2020).

Than, Krisztina. (2012). "Thousands rally against far right in Hungary." Reuters, Dec. 2, 2012. https://www.reuters.com/article/us-hungary-protest-nazi/thousands-rally-against-far-right-in-hungary-idUSBRE8B10CW20121202 (accessed on May 27, 2020).

Thorpe, Nick. (2015). "The baby that divided a nation". BBC News. February 8, 2015. https:// www.bbc.com/news/magazine-31168246 (accessed on May 22, 2020).

Thorpe, Nick. (2016). "Is Hungary's Jobbik leader really ditching far-right past?" BBC News, Nov. 15, 2016. https://www.bbc.com/news/world-europe-37976687 (accessed on May 28, 2020).

Varga, Mihai. (2014). “Hungary's 'Anti-Capitalist' Far-right: Jobbik and the Hungarian Guard." Nationalities Papers, 42 (5): 791-807.

Yilmaz, Mehmet. (2016). "'West uneasy with strong Turkey, Erdogan': Hungary MP." Anadolu Agency, August 5, 2016. https://www.aa.com.tr/en/europe/west-uneasy-with-strong-turkeyerdogan-hungary-mp/622101 (accessed on May 27, 2020).

Vona, G. (2012). "Turanism instead of Euro-Atlantic Alliance," Jobbik.com, https://dagobertobellucci.wordpress.com/2012/01/23/gabor-vona-turanism-instead-of-euro-atlantic-alliance/ (accessed on May 27, 2020).

Zalan, E. (2014). "Court Rules Jobbik Cannot Be Called 'Far-right'." Euobserver, June 6, 2014, https://euobserver.com/eu-elections/124509 (accessed on May 28, 2020).

Zimberg, Alexis. (2013). "Nostalgia and Notions of False Empire: The (Un)historical Rise of the Right in Hungary." The Hidden Transcript, Spring 2013: 28-32. https://issuu.com/the hidden_transcript/docs/ht4_print_070513_03 (accessed on May 28, 2020). 


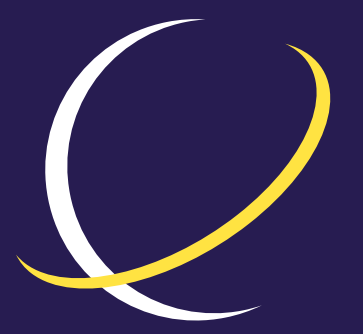

\section{ECPS \\ EUROPEAN CENTER for POPULISM STUDIES}

\section{ABOUT ECPS}

The European Center for Populism Studies (ECPS) is an independent, nonpartisan, nonprofit organization, based in Brussels, for research on and analysis of challenges posed by the resurgence of political populism. ECPS facilitates collaboration among networks of academic experts, practitioners, policymakers, media, and other stakeholders. ECPS offers a platform for the exchange of policy solutions on issues relating to rising populism and provides insights for policy-making and critical analysis to raise broader awareness and engagement through:

\section{Publications}

\section{Academic publications}

Policy reports

White papers

Commentaries

Podcasts and interviews with experts

Events, seminars, workshops, and conferences

\section{Research Programs}

Authoritarianism

Digital Populism

Economics

Environment \& Climate

Extremism \& Radicalisation

\section{Gender}

Human Rights

Foreign Policy

Leadership \& Persona

Migration

\section{ECPS Youth Program}

ECPS Academy 